Portland State University

PDXScholar

\title{
Feng Shui and Chinese Rituals of Death across the Oregon Landscape
}

Andrew Ryall Briggs

Portland State University

Follow this and additional works at: https://pdxscholar.library.pdx.edu/geog_masterpapers

Part of the Human Geography Commons, and the Physical and Environmental Geography Commons Let us know how access to this document benefits you.

\section{Recommended Citation}

Briggs, Andrew Ryall, "Feng Shui and Chinese Rituals of Death across the Oregon Landscape" (2002). Geography Masters Research Papers. 18.

https://pdxscholar.library.pdx.edu/geog_masterpapers/18

10.15760/geogmaster.18

This Paper is brought to you for free and open access. It has been accepted for inclusion in Geography Masters Research Papers by an authorized administrator of PDXScholar. Please contact us if we can make this document more accessible: pdxscholar@pdx.edu. 
Feng Shui \& Chinese Rituals of Death across the Oregon Landscape

\author{
Andrew Ryall Briggs
}

Submitted for partial fulfillment of Master of Science degree in Geography Portland State University

Approved by:
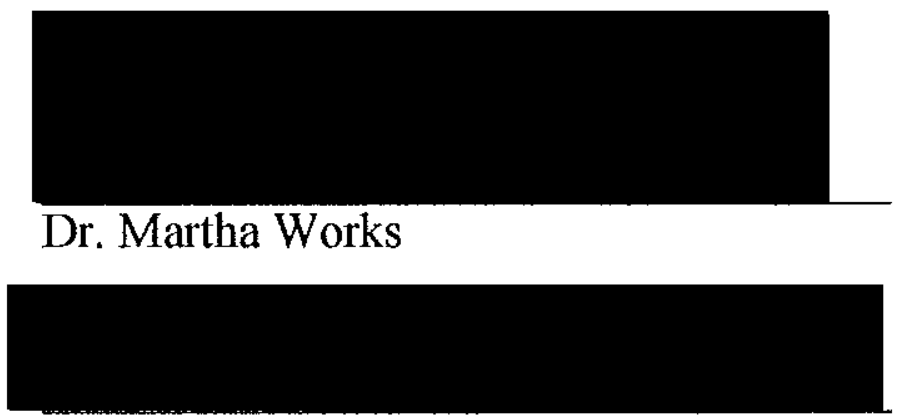

Dr. Teresa Bulman, Chair

Department of Geography

Date: mach 18,2002 


\begin{abstract}
An abstract of the papers by Andrew Ryall Briggs for the Master of Science in Geography presented March 13, 2002.
\end{abstract}

\title{
Paper 2:
}

\section{Feng Shui \& Chinese Rituals of Death across the Oregon Landscape}

Upwards of 20,000 Chinese migrated to Oregon before 1890. Upon their deaths many were interred in "Chinese cemeteries." In China, the placement of cemeteries is an important aspect of the traditional Chinese religion. This paper asks if the early Chinese practiced the same Feng Shui in the placement of the Oregon gravesites. While Feng Shui is not codified, there are a few general principles to determine graveyard placement, and by comparing Oregon Chinese gravesites with that required for proper Feng Shui placement, concluded that the early Chinese immigrants may have followed the precepts of traditional Chinese religion in siting. 


\title{
Paper 2
}

\section{Feng Shui and Chinese Rituals of Death across the Oregon Landscape}

By

\begin{abstract}
ANDREW RYALL BRIGGS
\end{abstract}
Papers submitted in partial fulfillment for the requirements for the degree of

MASTER OF SCIENCE

In

GEOGRAPHY

Portland State University

2002 


\section{TABLE OF CONTENTS}

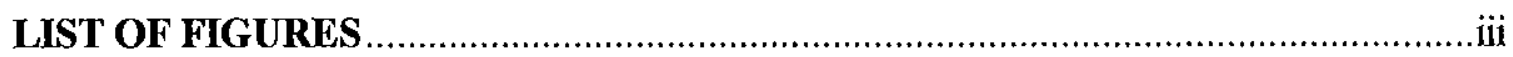

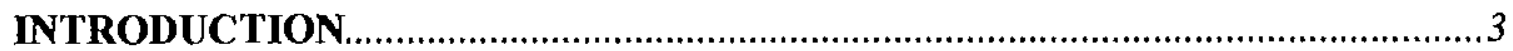

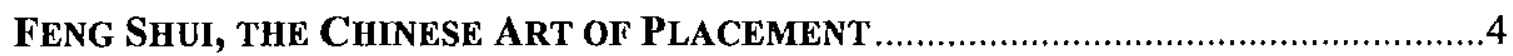

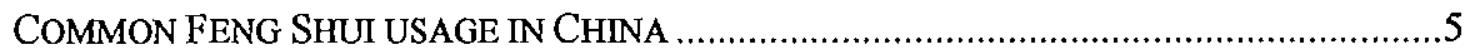

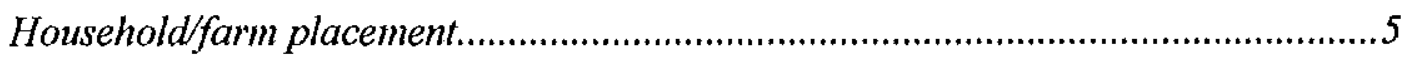

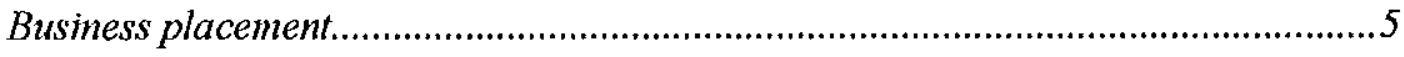

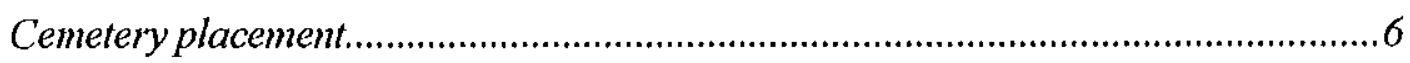

TRADITIONAL CHINESE RELIGION IN THE UNITED STATES ..........................................

THE DISTINCTION BETWEEN “GRAVEYARD” AND "CEMETERY" .................................

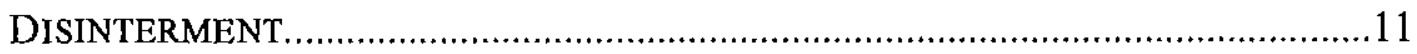

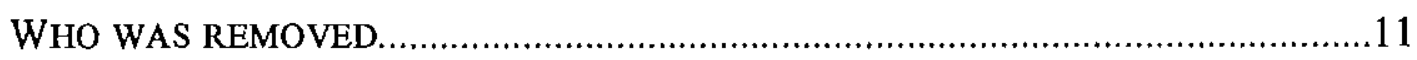

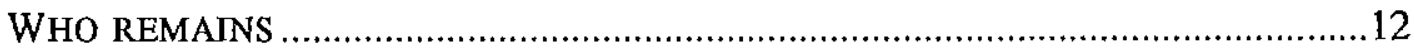

GEOGRAPHIC PLACEMENT OF CHINESE GRAVEYARDS IN OREGON .........................13

ASTORIA

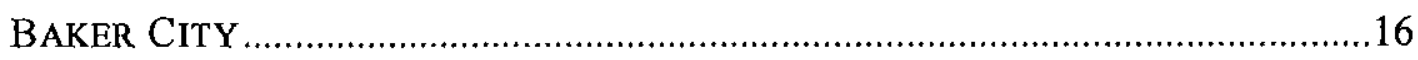

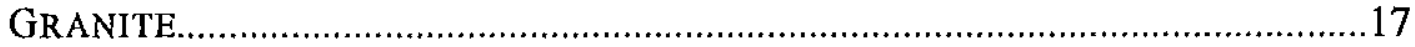

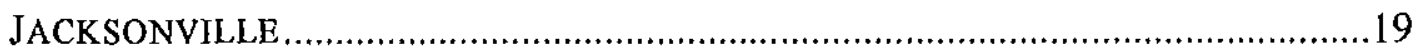

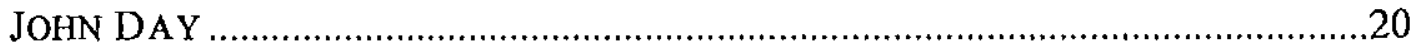

LA GRANDE

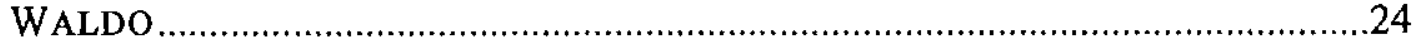

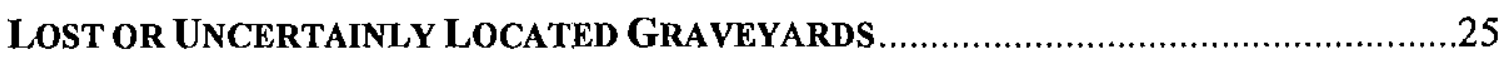

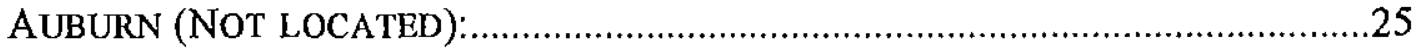




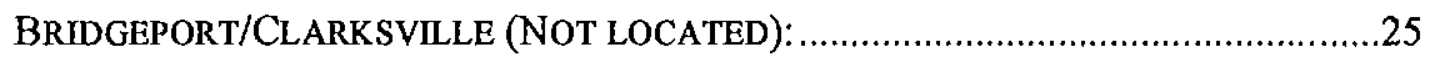

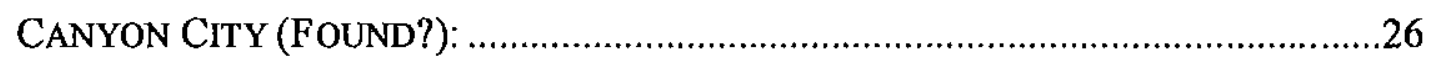

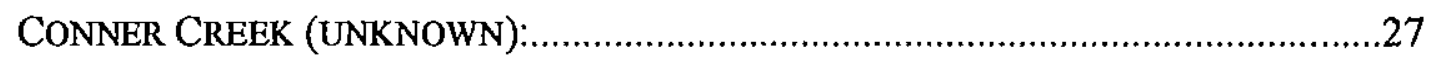

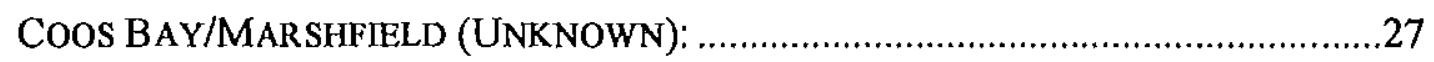

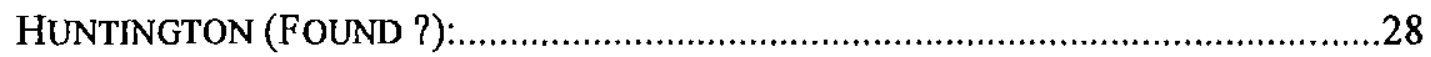

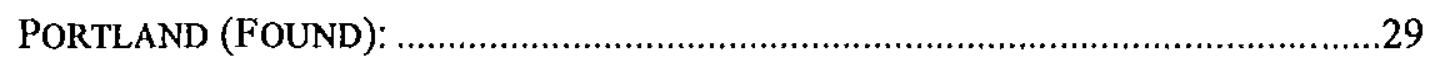

SPARTA: (FOUND 9):

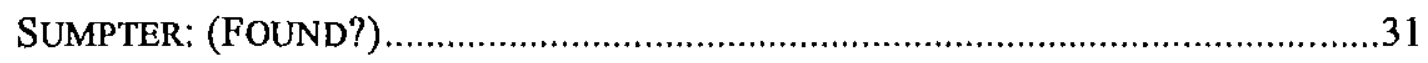

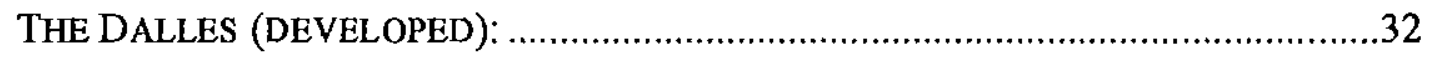

GENERAL REMARKS ON FENG SHUI AND OREgon CHINESE CEMETERIES ....32

CONCLUSION

BIBLIOGRAPHY 


\section{LIST OF FIGURES}

Figure 1: Overview of Chinese Cemeteries in Oregon ..........................................

Figure 2: Chinese grave marker from Canyon City, Oregon....................................8

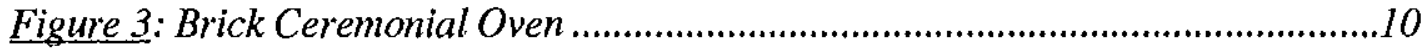

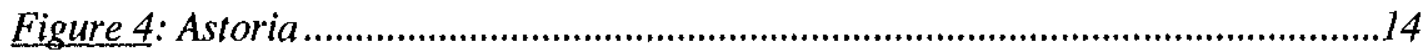

Figure 5: Astoria Post Card circa 1930............................................................15

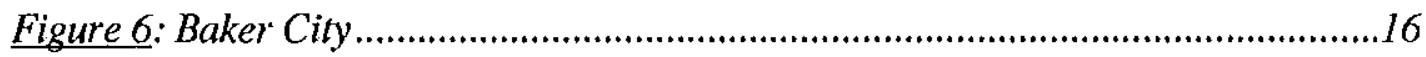

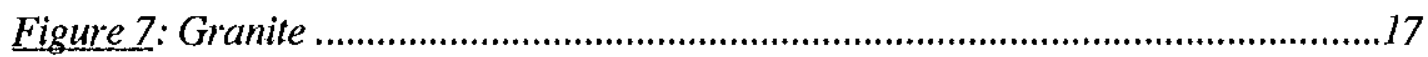

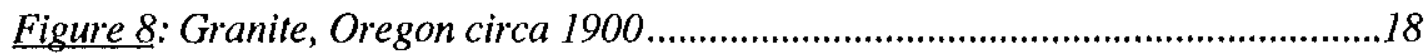

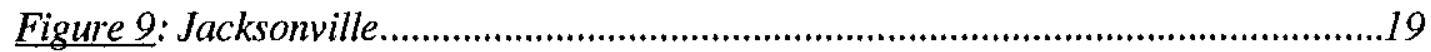

Figure 11: Photograph of John Day, facing North ..............................................21

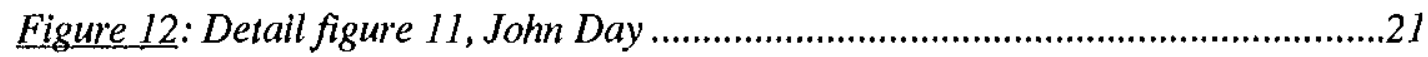

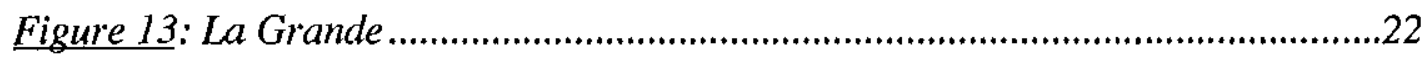

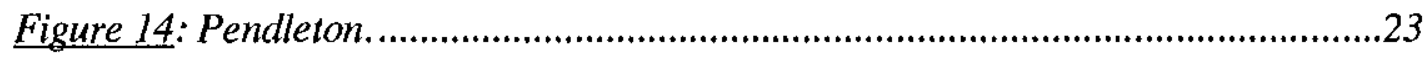

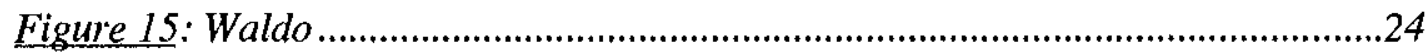

Figure 16: Late 1800s Canyon City postcard looking southwest............................26

Figure 17: Huntington Oregon postcard, looking southeast, circa 1900...................28

Figure 18: Detail from Sparta Oregon 7.5 topographic map ....................................30

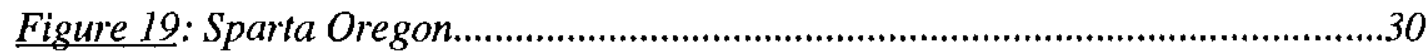

Figure 20: Detail from Brooks Hawley's Sumpter map ........................................31 


\section{Feng Shui and Chinese Rituals}

\section{of Death across the Oregon Landscape}

\section{Introduction}

Over 300,000 Chinese migrated to the United States between 1851 and 1900 (Coolidge, 1909). Most sojourners returned to China within their lifetime, but not all. There is no existing study as to the death rate of the Chinese in America, but it was said at the time that the Union Pacific Railroad was laid not across wooden ties, but on the corpses of migrant Chinese labor. ${ }^{1}$

The Chinese lived a hard life in Gum Shan, America, or literally translated, the Mountain of Gold. Mining and construction were dangerous activities, and necessitated primitive lifestyles, so Chinese cemeteries were comınon near every American Chinatown. As the Chinatowns dwindled and disappeared in the 1920s and 30 s, so too did the cemeteries. Many of the bodies were disinterred at that time to be shipped back to China, and most Oregon gravesites thereafter were left untended.

This paper uses contemporary records and field work to locate Chinese cemeteries, and then examines the use of feng shui in the placement of Oregon Chinese grave sites. The question motivating this review was whether the Chinese maintained the traditional cultural ways of death of China, or adapted to American funeral practices.

\footnotetext{
II is not coincidental that two of the better known contemporary expressions associated with the Chinese are "dead as a Chinaman" and "going to hell in a hand-basket" referring to the Chinese method of dynamiting pathways through the steep hillsides in the Rockies.
} 
Eighteen Chinese graveyards have been identified in Oregon (Figure 1). Eight of these graveyards have been mapped. These maps show the location of the Chinese cemeteries of Astoria, Baker City, Granite, Jacksonville, John Day, La Grande, Pendleton and Waldo, and their relationship to local topography, water and nearby town sites. Ten additional graveyards are discussed in the text, but not mapped due to vague records and altered landscapes. 


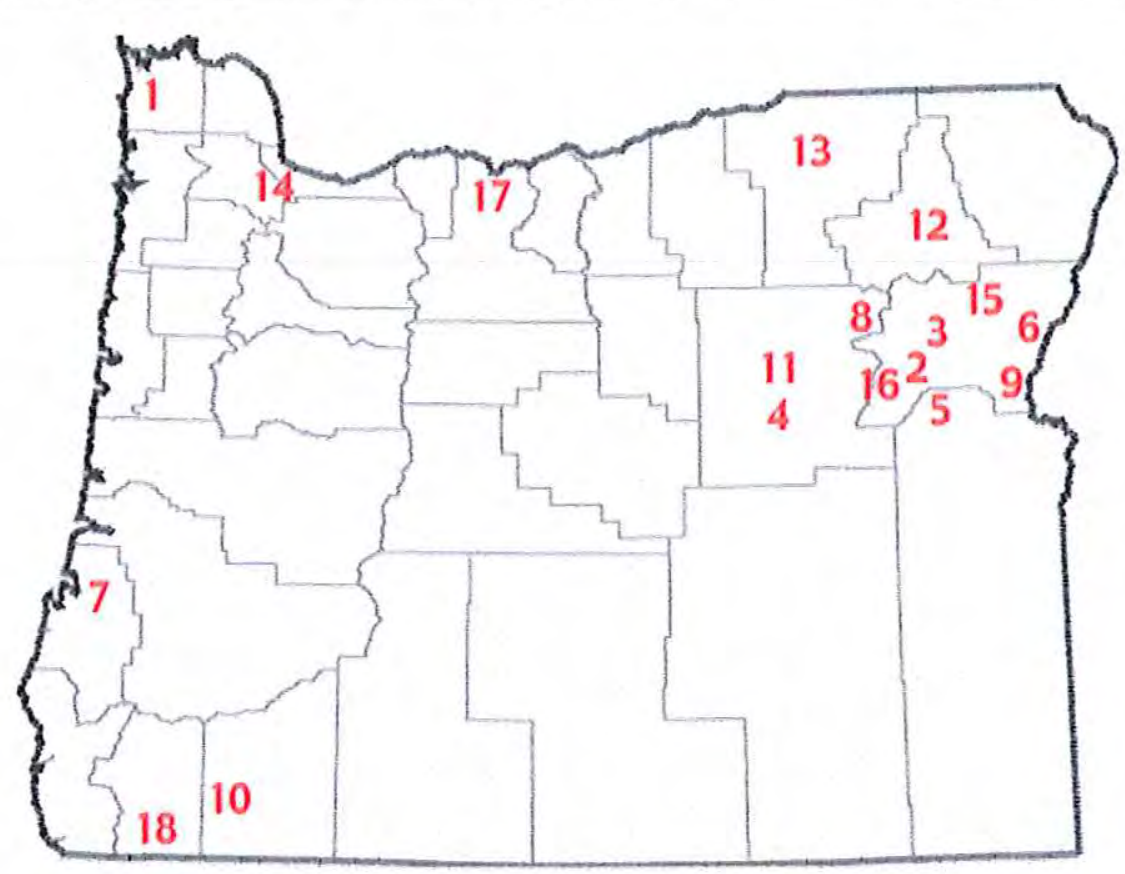

\begin{tabular}{|c|c|c|}
\hline Location & Name of nearest town & Status* \\
\hline 1 & Astoria & Found \\
\hline 2 & Auburn (abandoned town 7 miles south of Baker City) & Not Located \\
\hline 3 & Baker City & Found \\
\hline 4 & Canyon City & Found (?) \\
\hline 5 & Clarksville (abandoned town 20 miles east of Durkee) & Not Located \\
\hline 6 & Conner Creek (abandoned, 25 miles north of Huntington) & Unknown \\
\hline 7 & Coos Bay / Marshfield (incorporated into Coos Bay) & \begin{tabular}{|l|l} 
Unknown \\
\end{tabular} \\
\hline 8 & Granite & Found \\
\hline 9 & Huntington & Found \\
\hline 10 & Jacksonville & Found \\
\hline 11 & John Day & Found \\
\hline 12 & La Grande & Found (?) \\
\hline 13 & Pendleton & Found \\
\hline 14 & Portland & Found \\
\hline 15 & Sparta (abandoned town ten miles west of Halfway) & Not Locatec \\
\hline 16 & Sumpter & Found (?) \\
\hline 17 & The Dalles & Found \\
\hline 18 & Waldo (abandoned town 5 miles east of O’Brien) & Found \\
\hline \multicolumn{3}{|c|}{$\begin{array}{ll}* \text { Definitions: } & \text { Foumd: Site visited and confirmed the original sources. } \\
& \text { Found (?): Site visited but not confirmed with conflicting sources. } \\
\text { Not Located: Site visited and landscape significantly altered. } \\
\text { Unknown: Site not visited. }\end{array}$} \\
\hline
\end{tabular}

Figure 1: Overview of Chinese Cemeteries in Oregon. 


\section{Feng Shui, the Chinese Art of Placement ${ }^{2}$}

Feng shui ("wind/water" in the Kwangtung ${ }^{3}$ dialect) is the traditional Chinese practice of geographic placement. Practitioners, called feng shui sin shaang, use compass orientation and topography to situate houses, businesses, temples and graveyards, to insure good fortune to the occupants.

There are two schools of Feng Shui - the Kiangsi and Fukien Schools. The Fukien School (the "School of Functions") holds that human personality is determined by the five basic earth elements and the primary physical senses, and the Kiangsi School, (the "School of Forms") which relies upon the compass as a method of analyzing the landscape, and places far greater reliance on nearby topography. ${ }^{4}$

While it is apparent reading Chia-Lin Chen's PSU Masters Thesis of 1972 that the early Chinese immigrants to Oregon practiced a merge of Fukien and Kiangsi feng shui, Fukien has metaphysical underpinnings that defy interpretation, and will not be considered in this paper.

Kiangsi Feng shui is said to have originated near the Huang He (Yellow River), known as the "sorrow of China" because of its frequent flooding (Chen, 1972). The local population observed that people were affected, for good or ill by the proximity, topography and orientation of home and workplaces to the Huang He River. The early Chinese conceived of a magical link between man and the landscape, with some surroundings being better for luck and prosperity than others.

\footnotetext{
2 This overview draws from Frank Zhang's internet paper "Feng Shui and GIS" and Maurice Freedman's The Study of Chinese Society.

3Formerly known as "Cantonese."

${ }^{4}$ See Emile Durkheim's Primilive Classifications (1963), pp. 318-319.
} 
This is the basis of feng shui - that once the "magical link" is recognized, one's fortune can be influenced by the careful choice of surroundings. The task of a feng shui sin shaang practitioner then is to help situate human activity within the environment. If properly done, cosmic currents, know as $c h^{\prime} i$ will reward fortunes.

\section{Common Feng Shui usage in China}

Feng shui has three primary tasks: to locate household structures, businesses and gravesites for maximum $c h^{\prime} i^{5}$

Household/farm placement

As noted above, feng shui refers to wind and water. According to traditional belief, the best site would have proximity to both, yet not to excess. The "Breaths" (hei) of good fortune are of an ephemeral nature, and are carried away by a too brisk wind or too fast a river current.

An ideal site is one which nestles in the embrace of the hills standing to the rear and on the flanks; it is then like an armchair. Deficiencies in the line of hills can be made up by trees or, in extreme cases, by walls (Freedinan, 1979:192).

In addition, this ideal house would face south on a gentle slope, and have nearby running water, preferably just down the hill from the home. 0

Business placement

In the placing of shops, feng shui practitioners recommend corner lots as providing better $c h$ 'i. Shops are recommended to use bright colors to frighten away spirits, and follow the general 'lie' of the land, which would mandate building along main-roads, and not along minor streets cut-through hills.

5 Much of "Fuckien" geomancy discusses interior design at great length to maximize $c h$ 'i. This is barely discussed in the "Kiangsi" literature. 
Cemetery placement

Of special importance was the placement of tombs and graveyards, as the providence of both the gods and the inhabitants -- the site of ancestor worship. "Graves stand at the center of geomantic attention, and graves are the abodes of the ancestors" (Maurice Freedman, 1979:208). Traditional Taoist rituals of ancestor worship mandate filial duties to the dead, including sacrificial offerings to the grave sites, ritual unearthing and stripping of bones of the deceased, and general geomancy, particularly 'feng shui' positioning of the graveyard itself (Ahern 1973). Proper prayer to a male-ancestor (the gender issue will be discussed later in this paper) could result in enormous $c h^{\prime} i--$ but ancestors are remarkable fickle.

There is a strong belief in geomancy (feng-shui) and in particular in Feng-shui of the Yin-Chai type, concerned with Gravemaking.... Attention paid to graves is...great because...descendants want to ensure not only the peace and contentment of the ancestor buried in the grave, but also the good fortune accruing to themselves through the effects of feng-shui (apparently) on the grave itself (Baker, 1968).

The recommended cemetery site would be similar to that suggested for house-

placement. Halfway up a hill in a hollow or protected spot, but facing north, which had symbolic meaning in the Chinese after-life.

\section{Traditional Chinese Religion in the United States}

Three hundred thousand Chinese immigrated to the U.S. before 1900 (Coolidge, 1909). It is unknown how many of these immigrants came to Oregon ( $K^{\prime}$ o-li-chin in) before 1900 , but the 1870 census recorded 3,300 , and the 1880 census 9,500 Chinese 
living in the state (Edson, 1974:33). The actual numbers were certainly higher. ${ }^{6}$ Many of these first immigrants settled in Oregon Chinatowns, and many of these Chinatowns had their own religious temples, called "Joss houses" for the local community. ${ }^{7}$ The larger Chinatowns in Portland, La Grande and Baker City had such formal temples, while many of the smaller communities used "Kitchen Gods"- deities for the immediate community (Barlow, 1979).

Contemporary Anglo records from the 1800 s do not discuss the rituals associated with the Joss houses, but do report on the commonly witnessed Chinese death rituals. The descriptions are consistent, and describe the same Chinese ceremonies as would be performed in China, including feast days, burning of incense, offerings to the decedent and burial practices.

On the day of the funeral a platform or shed would be built, with a framework of white banners, and usually one tall vertical banner would give the name of the man who had died and some of his deeds and his relations. Food and wine would be offered to the deceased for the Journey. There were deep fried noodles, dyed red, yellow, and green, which couldn't be eaten, actually. Fruit, wine, and imitation foods of other kinds would be offered, too. While the coffin was at rest, there vould be the wailing of all the children and relatives of the deceased (Nee, 1973:107).

Chinese funerals in the early days of Huntington were elaborate affairs with singing and shouting as the procession made its way to the cemetery. Firecrackers were exploded along the route, and a group of musicians would march along playing loudly on their instruments. The noise was to frighten away the devil (Sisley, 1975:11).

Some Chinese would go in front and scatter all along the road pieces of thin paper resembling tissue. These were about four by six inches and had

6 Due to 'Chinese' taxes and harsh enforcement, the Chinese viewed census-takers as potentially dangerous, and avoided head-counts. One estimate suggests that the actual number of Chinese in 1880 was at least twice the 9,500 census sum (Barlow, 1989:14). 7 The temples were called "Joss houses" in the Anglo accounts. The word "Joss" appears to be a corruption of the early Portuguese explorers word for God, "Deux" (Wegars, 1993). 
many small holes in them, much as though a pencil had been shoved through as often as possible without making the holes join. They told us that the devil had to go back and forth through all these holes before he could overtake the corpse (Oliver, 1961:159).

All the deceased's papers were burnt in the brick oven [at the cemetery]... Food was provided and set out on the newly made grave so that the departed might not go hungry... [T] he dead was given a coin to hold in the mouth, with which to pay admission to heaven (Lund: 1947:4).

Bodies would then be buried, and later disinterred for shipment back to China.

\section{The distinction between "Graveyard" and "Cemetery"}

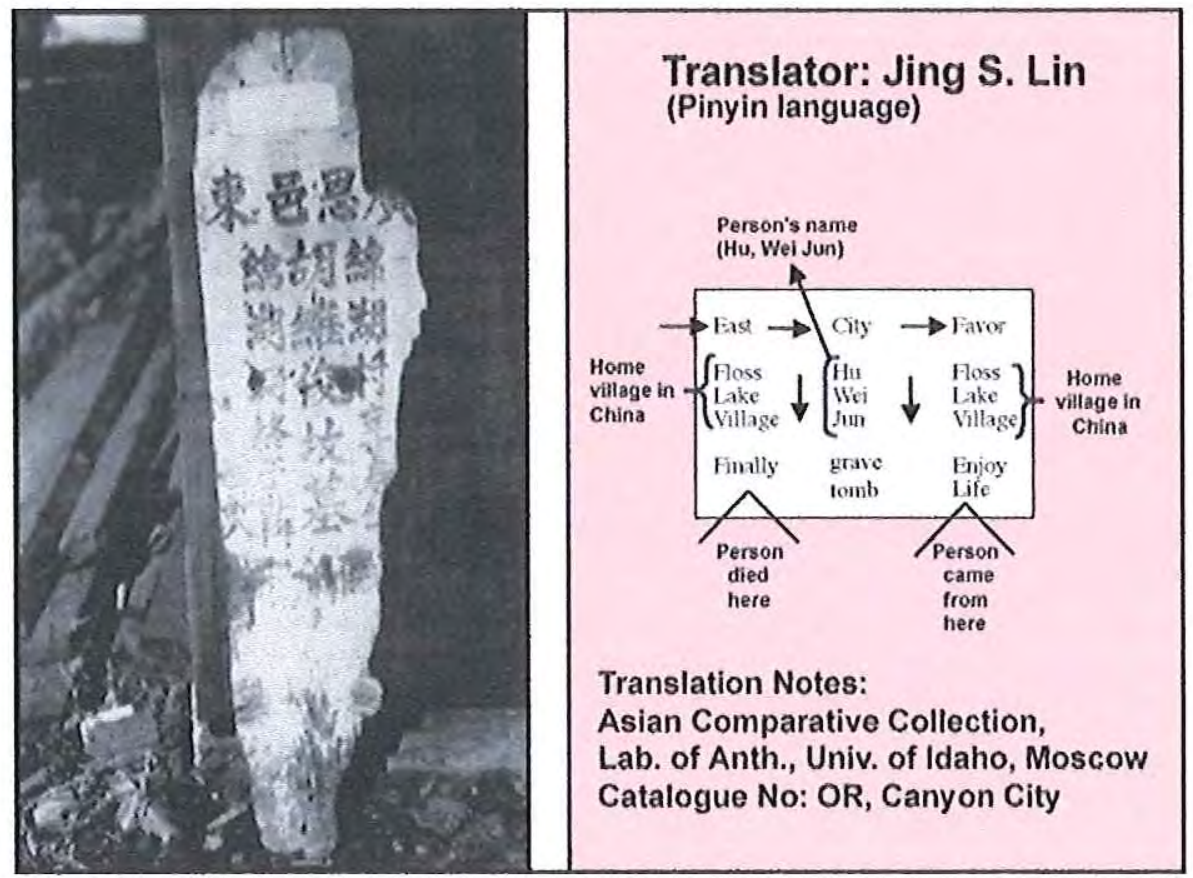

Figure 2: Chinese grave marker from Canyon City, Oregon ${ }^{8}$

The early Chinese loathed the idea of permanent interment in the United States (Couch, 1996). Instead, they would arrange for their corpses to be disinterred after several years and the bones scrapped and returned to the family plot in China (Ahern, 1973).

${ }^{8}$ Marker photograph from Pioneer Trails, Umatilla County Historical Society, Vol. 16, 2, 1992. This specific marker is at the Prairie City Depot Museum., Prairie City Oregon. 
The marker in Figure 2 is a good example of how the graveyard would be used. This marker, from a Canyon City Oregon gravesite has been translated from the Pinyin language to read: "East City favor /Wei Jun Hu came from Mian Hu village and finally [died] Mian Hu village"9 The translation doesn't make literal sense - Wei Jun Hu died in Oregon, but desired his bones to return to Mian $\mathrm{Hu}$, and the marker above his corpse asks this favor - to return his corpse to his home village, identified twice on the marker.

Many of the burial plots across Oregon could be viewed as such temporary sites -where the body could be stripped of flesh, easing later transportation and lower costs in the shipping of bones back to China.

Mr. Yong Bo died at his home in Dry Gulch last week, and was buried by his celestial comrades beneath upwards of 6 " of mother earth. These heathens ought to be compelled to plant their diseased carrion deeper (Grant County News, 1886). ${ }^{10}$

A shallow gravesite facilitates this later disinterment, and although actual numbers are unknown, most of the corpses were removed and shipped back to China by the 1930s (Wegars, 1995).

Not a single pre-1900 tombstone (as opposed to wooden marker) exists in any of the assorted graveyards in Oregon. ${ }^{11}$ This again indicates the temporary status of the interment-- stone cost more, and suggests permanence, so wood would be the preferable choice.

9 The translation was done December 27, 1989 by Jing S. Lin for the Laboratory of Anthropology, University of Idaho, Moscow. Her translation is on file at the Kam Wah Chung museum in John Day Oregon as personal correspondence on 24 January 1990. Note that the literal translation doesn't say 'died' but "finally/grave/tomb." ${ }^{10}$ Grant County News-Canyon City, Thurs. Feb. 4, 1886, page 3, Col.1, paragraph 7. Collected by Janise J. Justice, curator, Herman \& Elisa Oliver Historical Museum. 
Yet counter to this temporary status of Chinese graveyards are the still-existing brick ceremonial ovens (also called "prayer houses") built in Pendleton and Baker City, and others, now demolished, in John Day, Astoria and Jacksonville (Wegars, 1995). The structures were intended to house spirits, and store food and gift repositories for the souls of the departed, and as burners "to honor the departing spirit by burning punk incense and prayer papers" (Wegars, 1995).

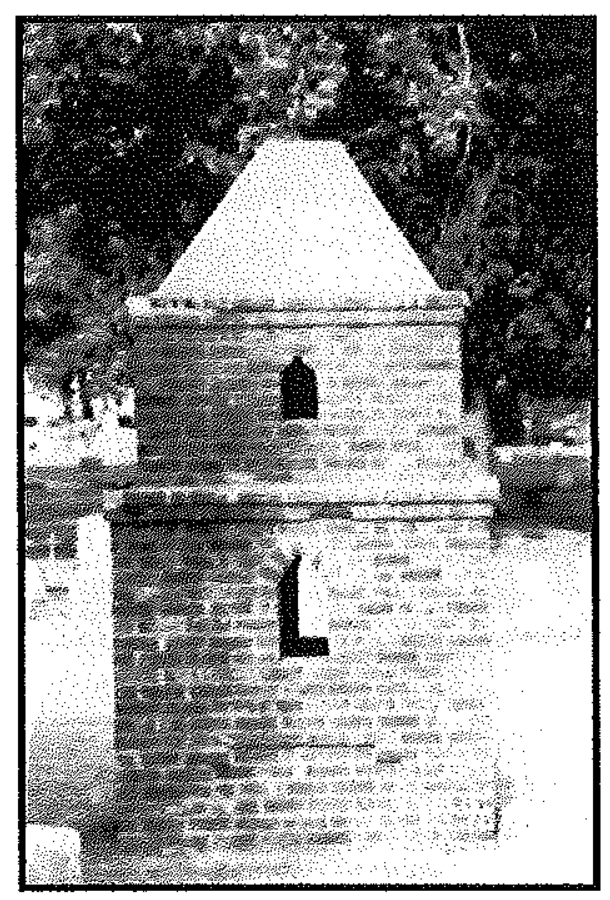

Figure 3: Brick Ceremonial Oven ${ }^{12}$

These are solid structures, and denote permanent cemeteries.

The distinction between what is a Chinese "graveyard" (temporary gravesite) and a Chinese "cemetery" (permanent gravesite) cannot be accurately determined. Bodies were left in both, and disinterred in both -- the records are not clear. What is apparent is that

11 Concrete and stone Chinese tombstones do exist in John Day, Portland and Baker City, but all are post- 1900 .

12 Photograph from Pioneer Trails, Umatilla County Historical Society, 1992. 
many were not exhumed. In one study of the Baker City cemetery, it was concluded that at least thirteen of the forty-five known Chinese corpses at that site remain interred (Wegars, 1995).

\section{Disinterment}

Many Chinese sojourners wanted to return to China.

(Headline) Orientals Going Home to Die: Aged Chinese...to be buried beside bones of their ancestors. Since the San Francisco earthquake and fire, nearly 2,000 Chinese have left the ruined city for their native land....In nearly every case the Chinese returning is old, decrepit and indigent. In fact, he is going to his home for the sole purpose of dying. The Chinese have a horror of passing away in this country, and the last effort of nearly every individual is to get back among his own people. (Oregonian, circa 1906 in Chen, 1972, 118).

Exhuming and shipment of the corpse/bones of the Chinese who did not make it back to China was the next best possibility.

Frequently one dies here and is given the usual burial. Every two or three years the bones of the dead are exhumed, scraped and prepared and shipped to the relatives in China..." (Ibid.)

\section{Who was removed}

Transportation to and from Gum Shan was expensive -- the average laborer could not afford the trip from China to the Gold Mountain of America. Thus, associations fronted the necessary travel money as a loan. The laborer was indentured upon arrival to work as manual laborer for the same association, who 'rented' out their services to interested parties. Transportation back to China was not permissible until the original loan was repaid to the association (Nee, 1973; Chen, 1972). I have found no information as to loan 
repayments or forfeitures, but the general trend is clear -- the associations controlled who returned by controlling employment and loan repayment. ${ }^{13}$

Several of the associations had the equivalent of 'burial insurance' -- guaranteeing shipment of the body back to China after death (Wegars, 1995). While this 'burial insurance' appears to have been well-subscribed, the majority of disinterments were paid for by Chinese Government and completed in the 1920s (Wegars, 1997). At this time most of the male Chinese who died in Oregon were removed. Most of the women were not.

\section{Who remains}

In the 1870 Census, $61 \%$ of the 3,536 women of Chinese ancestry in California listed their occupation as "prostitute" (Hirata, 1979). The 1870 Oregon census only lists 98 women of Chinese ancestry - of these 64 listed their employment as "prostitute." If these women died in the United States, it is doubtful their bodies were removed back to China.

The traditional Chinese religion was paternalistic, with Chinese of the 19th century believing that women had no souls (Takaki, 1979). Women were not part of traditional 'ancestor worship,' but mere vessels on earth, and not required for future $c h$ 'i by

13 Much of the labor worked by the Chinese was seasonal -- and loans would be tendered in the winter-months by the association to help the laborer over the 'dry spell.' Unfortunately, this continued the cycle of debt and loan-repayment, (usually with interest) of the average Chinese laborer. The situation was not unlike that of the 'Company town' of the Appalachian coalmines, where the laborer was poorer after joining the work force than before. 
descendants. In addition, these women were "a thousand men's wives."14 It was

unlikely, due to the status of gender and profession that their bodies would be returned.

At least eight female bodies remain in the Baker City graveyard (Wegars, 1996). One can predict similar numbers across the state.

\section{Chinese Graveyards in Oregon}

There are no records regarding Feng Shui usage in the placement of graveyards in

Oregon. The only record of Feng Shui placement in the U.S. prior 1900 was for the

Colma, California Chinese cemetery.

The [Chinese] cemetery was... in Lincoln Park right next to the present Legion of Honor Museum. That was mostly for Chinese seamen, who had their own burial society and their own cemetery. They chose the spot, which at that time was completely desolate, by having a specialist study the shan-shui (sic feng shui) or "wind and water" configuration, to determine a place which would please the deceased and be auspicious for the relatives... It's on a little hill looking out over the Pacific Ocean." (Interview with Ching Wah Lee, in Nee, 1973).

Oregon has several Chinese cemeteries. Below are maps of eight known sites, as well as some general comments on lost or unverified Chinese cemeteries.

${ }^{14}$ Seven family surnames predominated in early Chinese American history. The Chinese organized along these family lines into Associations, (incorrectly referred to as 'Tongs' by early Anglos). A prostitute born to the "Hay" clan would change her name, ("A 1000 men's wife" being a commonly used alias) so as to not bring shame to her family-name, and to not lower her customer base, (a male "Hay" would not sleep with a female "Hay" as a presumed familial relationship existed between them). As a result of this namechange, the Associations, (which controlled the women in near-slavery conditions) had less of a responsibility to return them to China as they were no longer a 'named' member of the clan. 

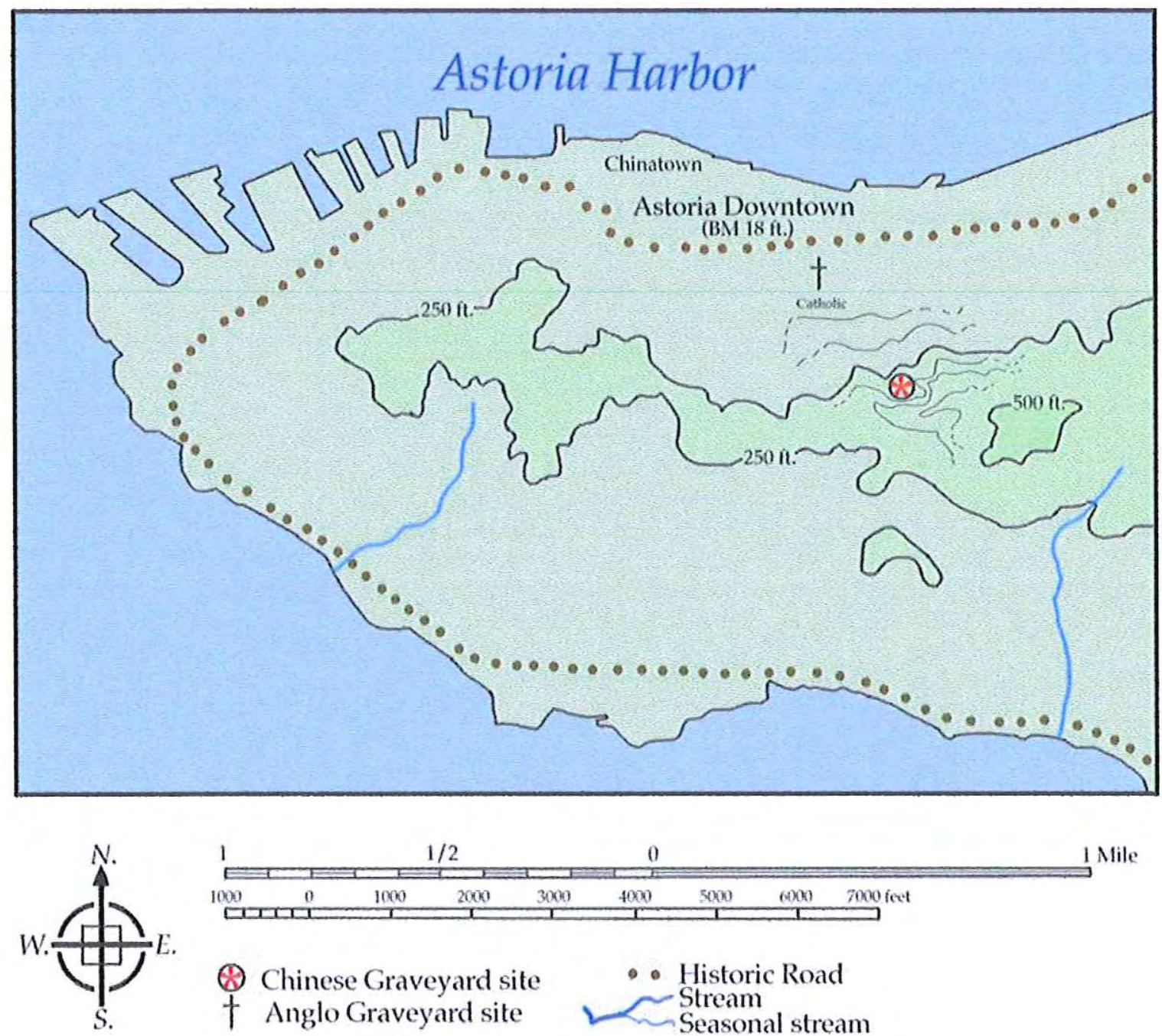
1 Mile

Figure 4: Astoria

On the hill south and up from Farmers' wharf (Near $16^{\text {th }}$ and Coxcomb St. in modernday Astoria.) The site is now forested, and I was unable to locate gravesites. 


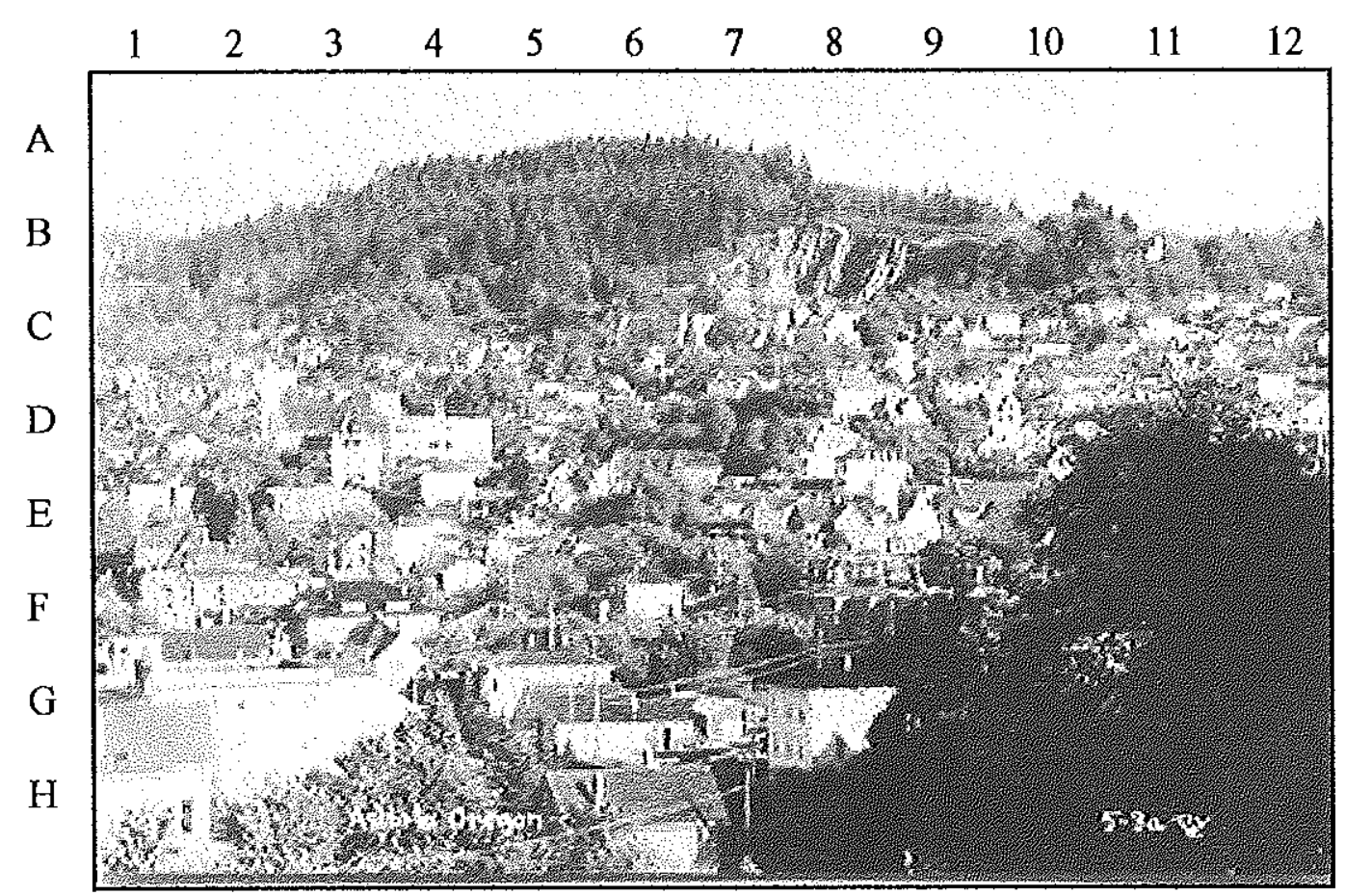

Figure 5: Astoria Post Card circa 1930. Collection of the author.

Astoria had the second largest Chinatown in Oregon in 1880. Chinatown was left of the above postcard at modern-day $7^{\text {th }}$ and Bond. The Chinese cemetery would be located neat the top of the hill in the background around $\mathrm{B}, 11$.

A Heathen Rite: On Tuesday afternoon six Chinamen and a boy were seen wending their way up to the graveyard on the lill south from the Farmers' wharf (near $16^{\text {th }}$ street), bearing a roasted hog, a pan of cooked rice, a lot of cakes, bottles, etc.... When the graveyard was reached, the Chinese halted in front of a row of five graves [and] stopping before each grave [made] three low bows with hands clasped above their heads, then placing lighted colored candles at the head and foot of each grave, beside some other performances with grub, etc... when all was over, the Chinese heartily fell in and commenced to lunch upon the pork and other edibles and drinkables....The spokesman explained that this ceremony of feeding the dead was a duty enjoined three times a year, and was performed in March, July and October, varying with the new moon (Oct. 28, 1879, The Daily Astorian, sited in Penner, 1990). 

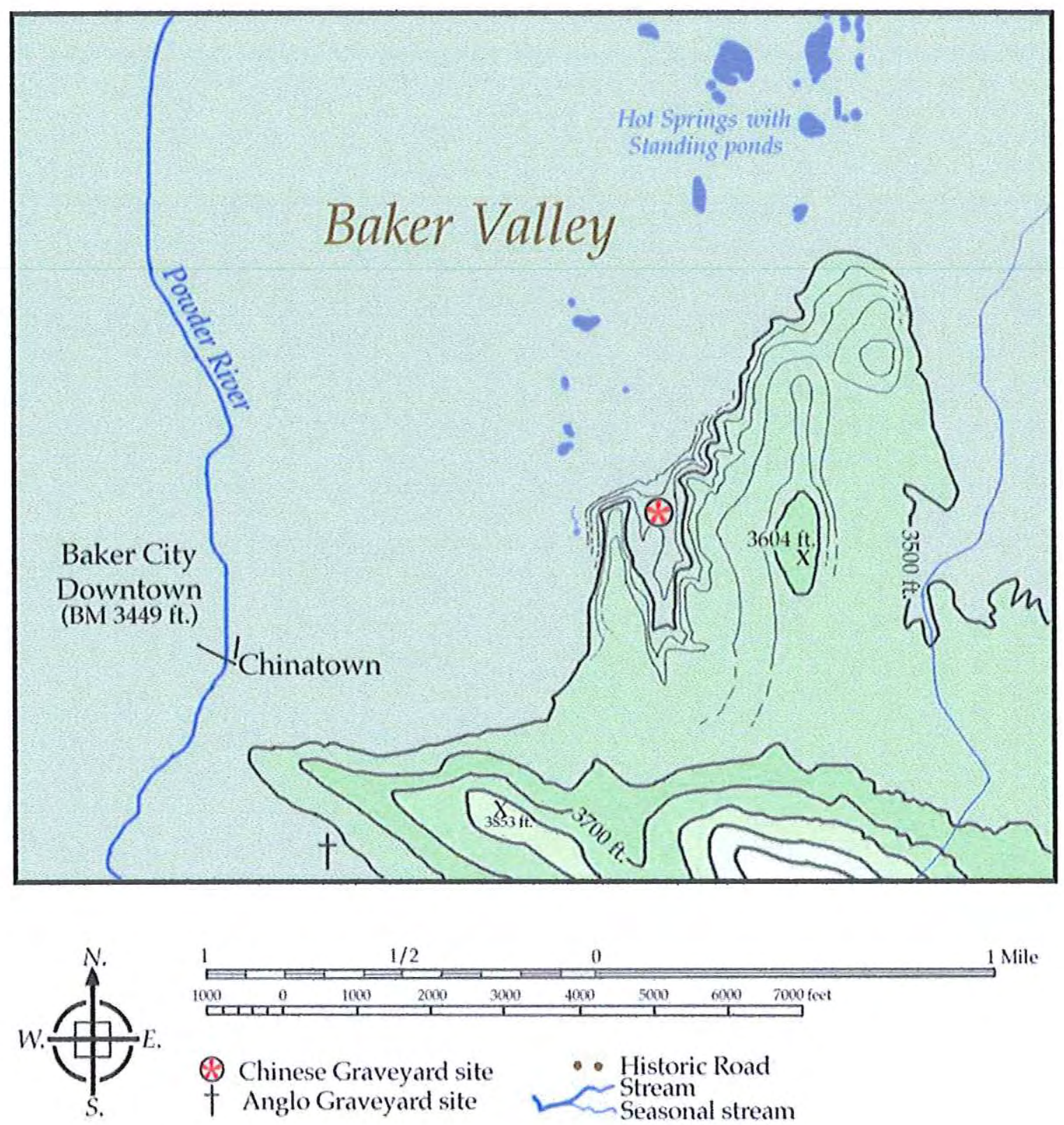

Figure 6: Baker City

Located 100 yards southeast of the Texaco Station on Atwood Street, which itself is just east of the I-84 freeway exit to Baker City, (exit 304). The cemetery has been designated a Historic Preservation site, with several stone markers surviving. A ceremonial oven was recently built using stones from the original structure on the same foundation. A recently constructed dirt roadway is sliding into the cemetery. 

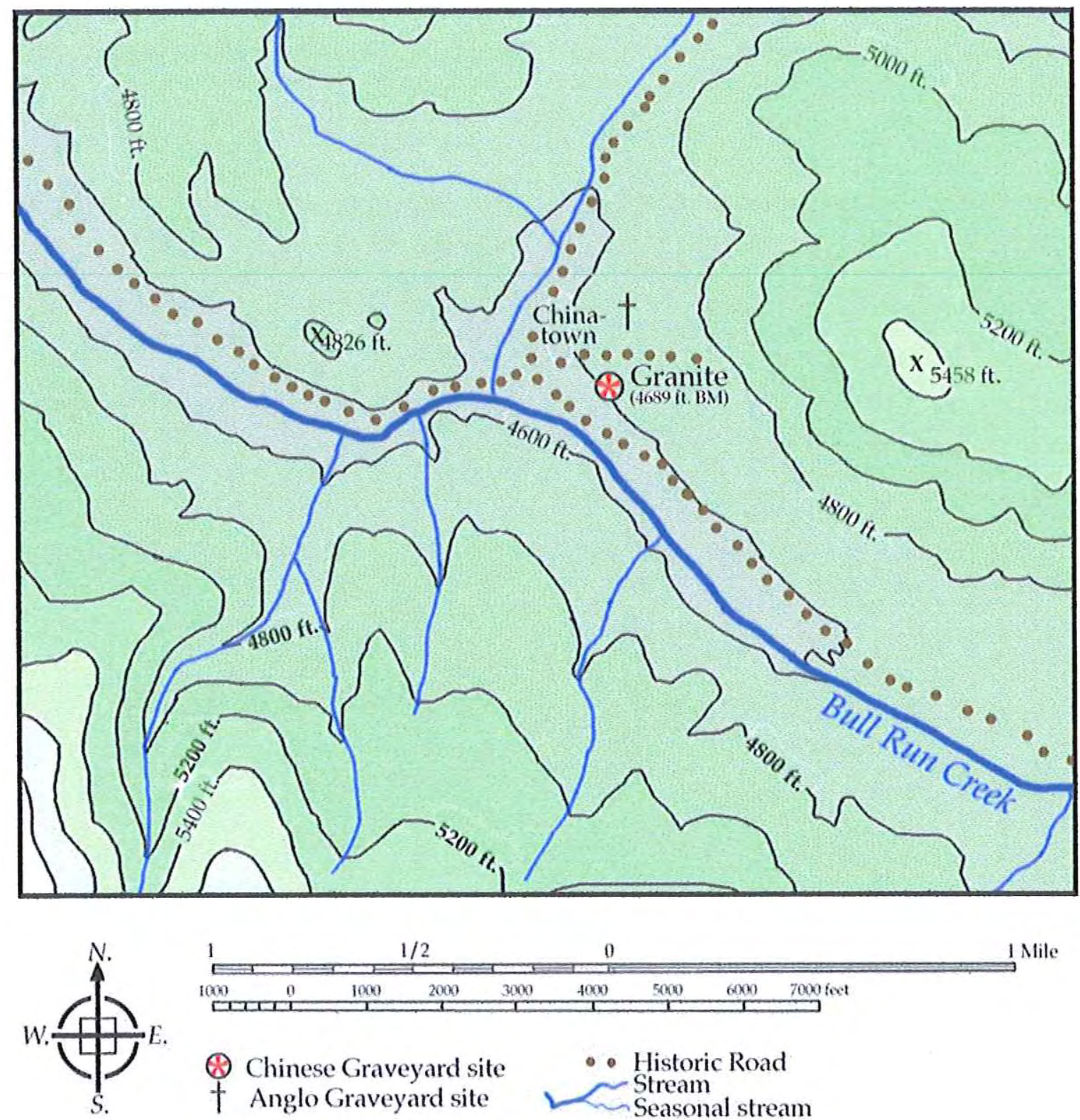

Figure 7: Granite

An abandoned hillside approximately 25 yards east of intersection of Center and NFD 73. Photograph of Original cemetery (see figure 8) helps fix the location. 


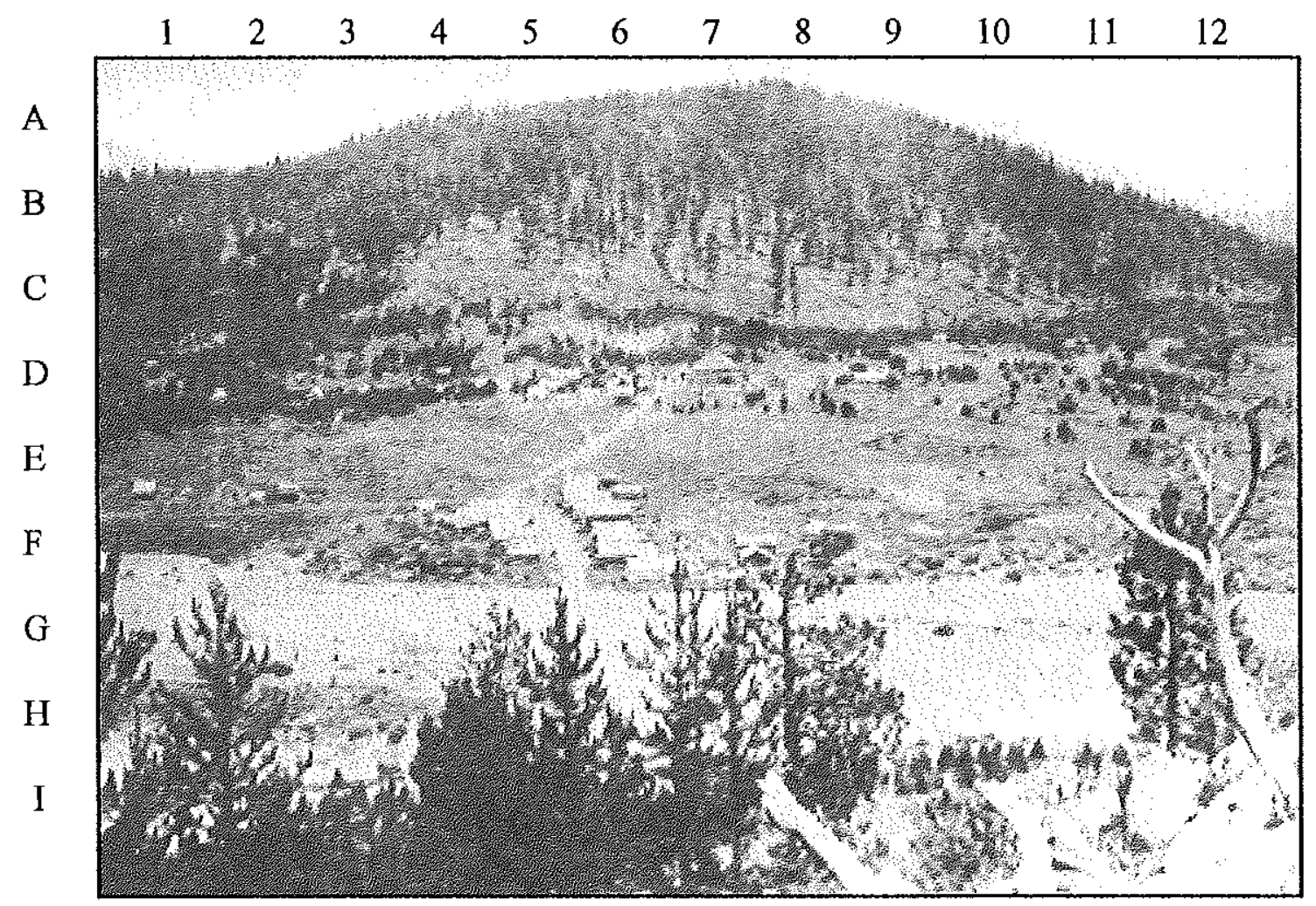

Figure 8: Granite, Oregon circa 1900

Chinatown, with a population of approximately 150 in $1890-1900$ is at 6 , E. The Chinese Cemetery is the dark patch of ground at $8, \mathrm{E}$. 

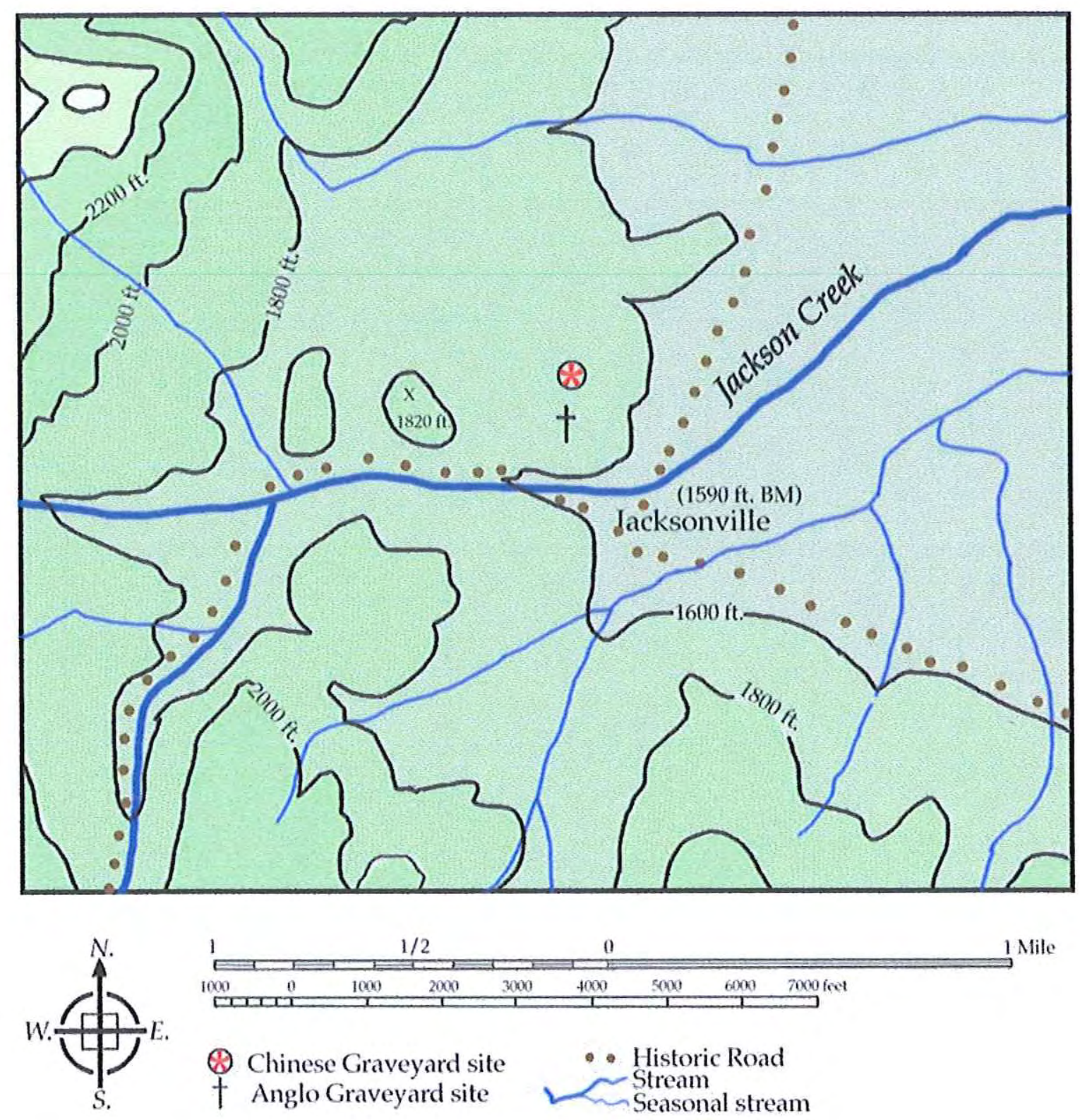

Figure 9: Jacksonville

To the north of the existing Jacksonville cemetery, now covered by a stand of Oregon Oak. No remaining tombstones or evidence of gravesites. 

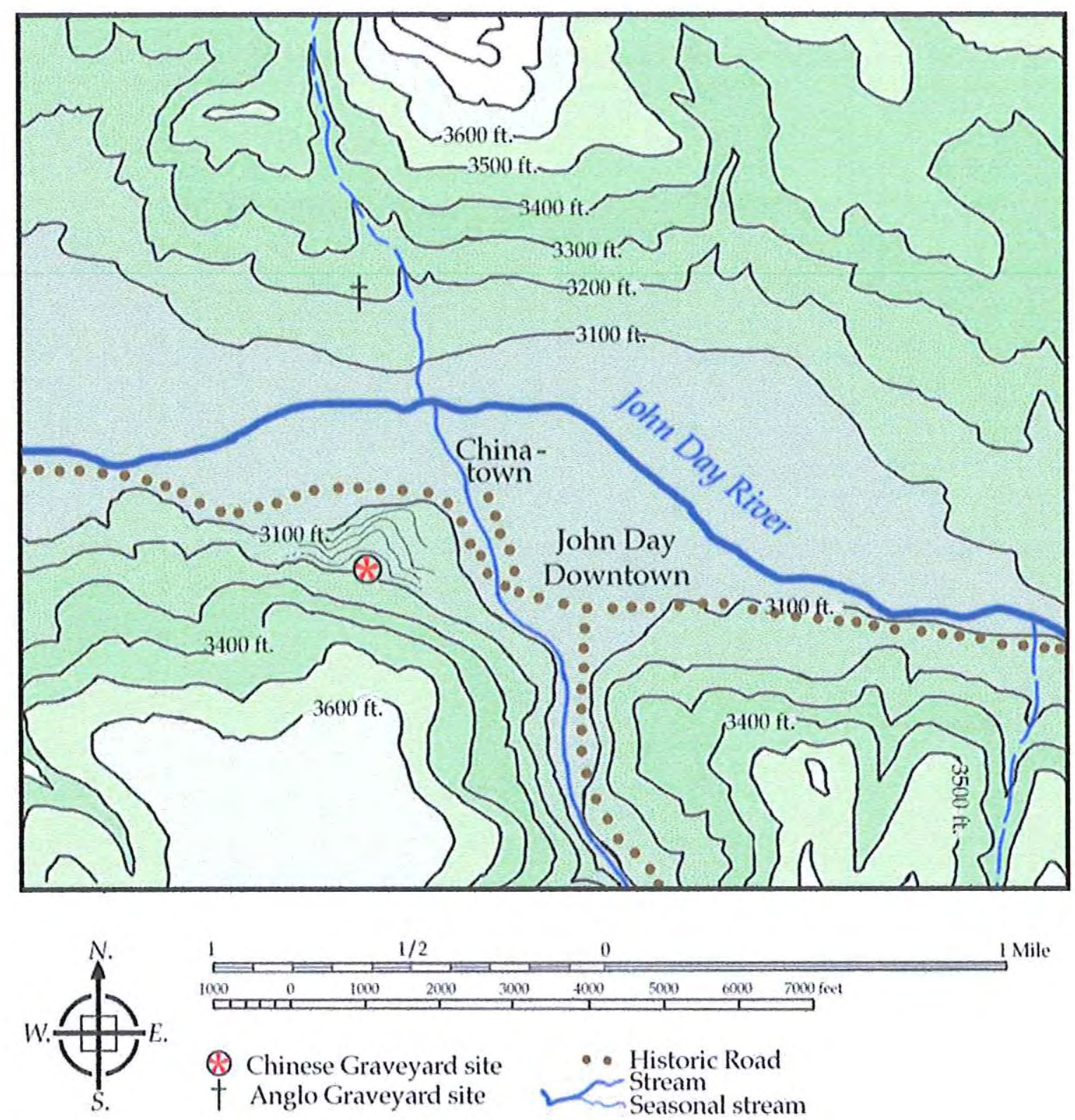

Figure 10: John Day

The former graveyard is on private property on a hillside above a trailer park, approximately 1/2 mile southwest of Kam Wah Chung Museum. The land is used as horse pasture. Ing Hay and Lung On, former owners of the Kam Wah Chung, are buried in the.Anglo Graveyard, shown 1 mile north of the Chinese gravesite. No evidence of burial sites remain at the Chinese cemetery. 


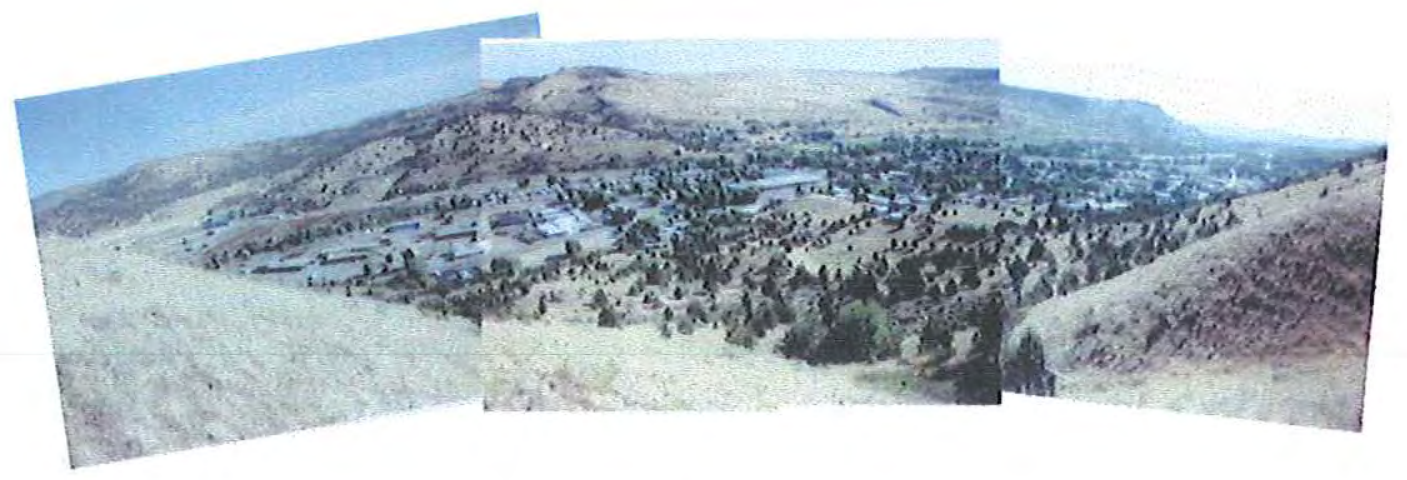

Figure 11:Photograph of John Day, facing North (photograph by Author)

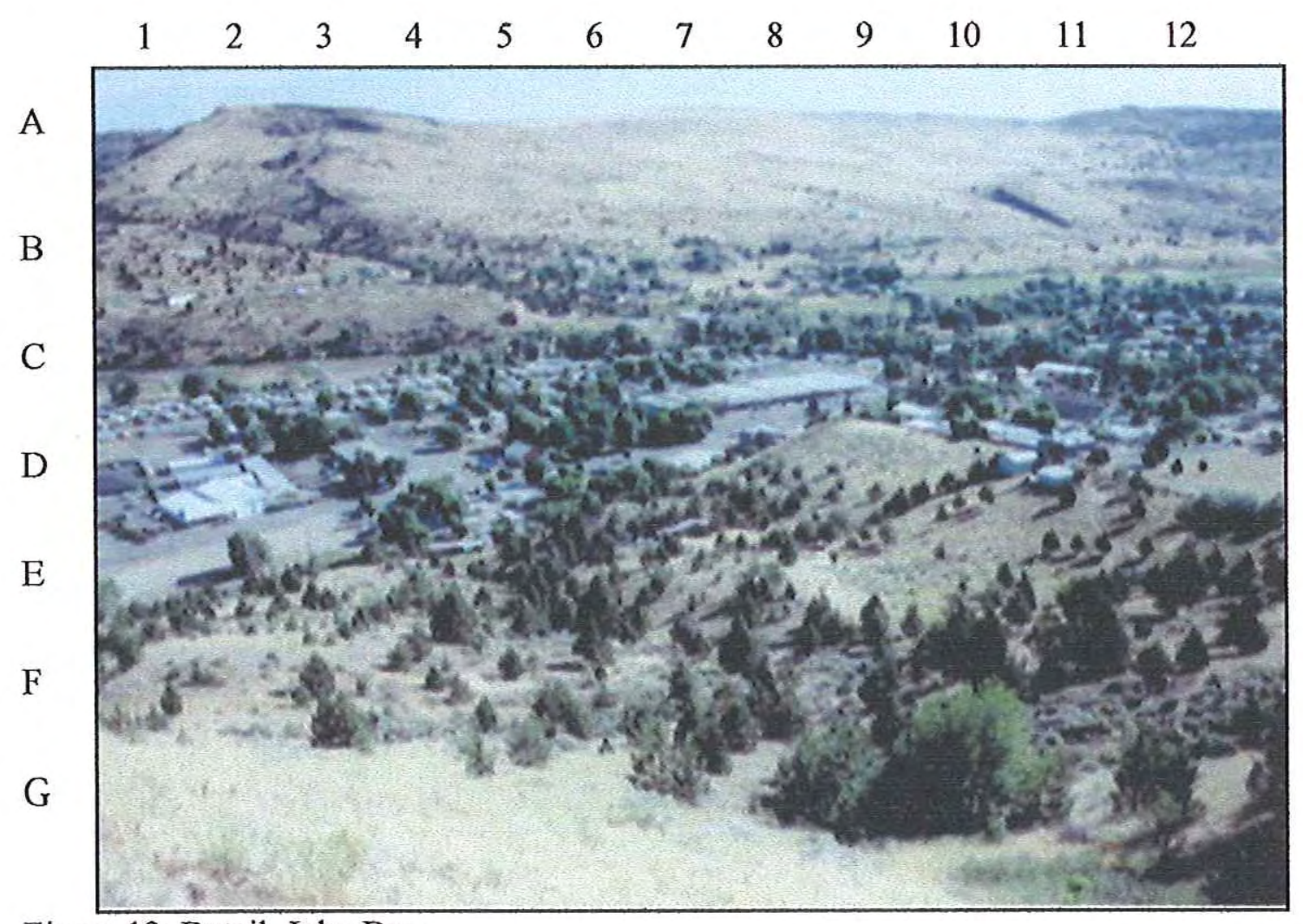

Figure 12: Detail, John Day

The Chinese cemetery is at $8, \mathrm{E}$. The land is pasture for a horse barn on the ridge to the east (right) of the photograph. The Anglo cemetery, at B, 5 is where Ing Hay and Lung On are buried. Chinatown was around 11, C. 

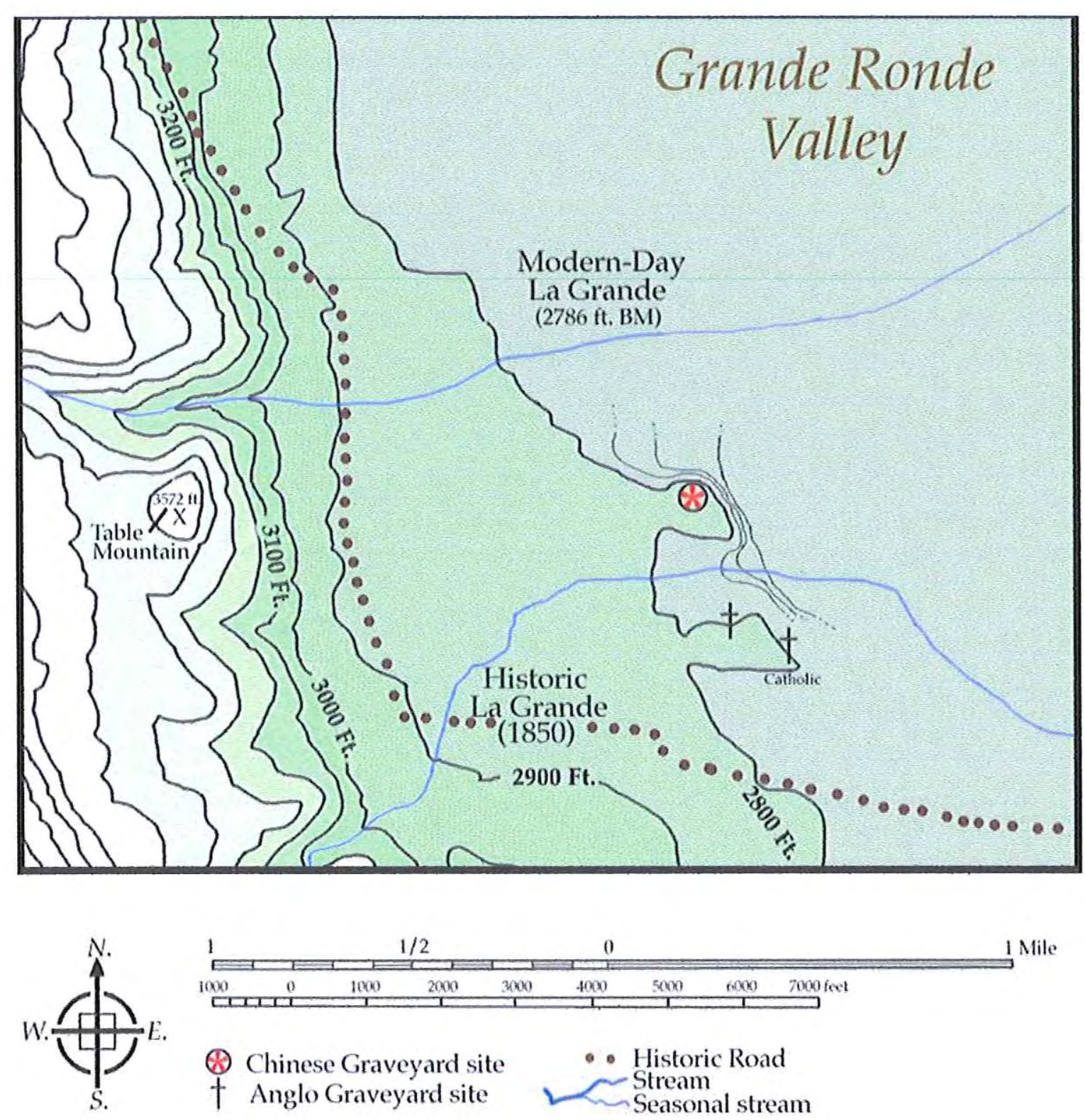

Figure 13: La Grande

Under the E.O.U. campus administration building on the hill above the intersection of 10th and $\mathrm{L}$.

Note: While La Grande had an active Chinatown this is a problematic cemetery. While this site held several bodies, it is unknown if these were from the local Chinese community, or railroad workers who died in the region and buried on what was then railroad land. The landscape has been severely altered. 

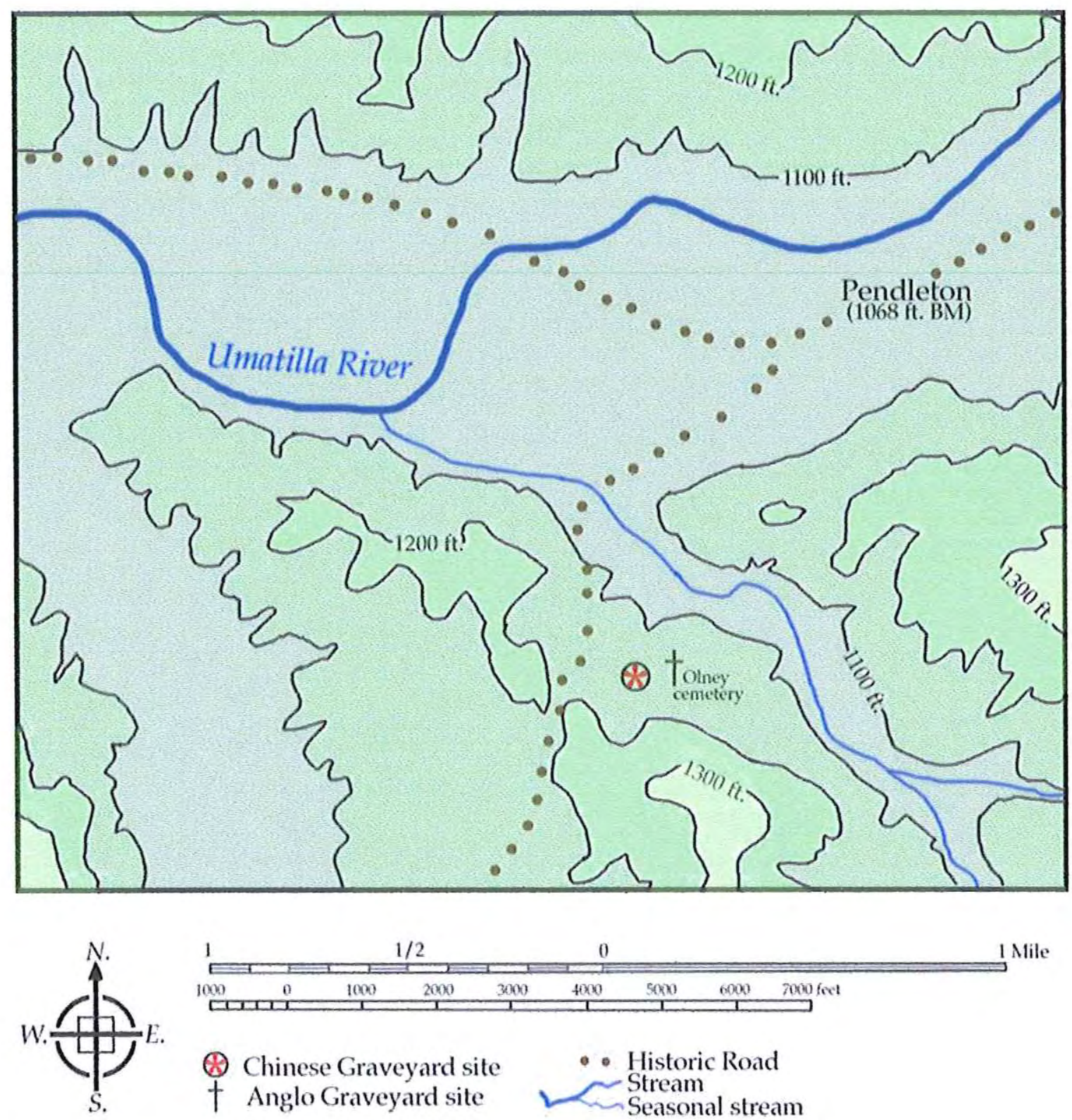

Figure 14: Pendleton.

The Chinese graveyard is found in the southwest corner of the Olney Cemetery, on the hill south of downtown Pendleton. The site has had recent burials, but no Chinese tombstones survive of prior 1900 . The cemetery has a brick ceremonial oven, which is rare- only Baker City and Pendleton have ovens remaining. 

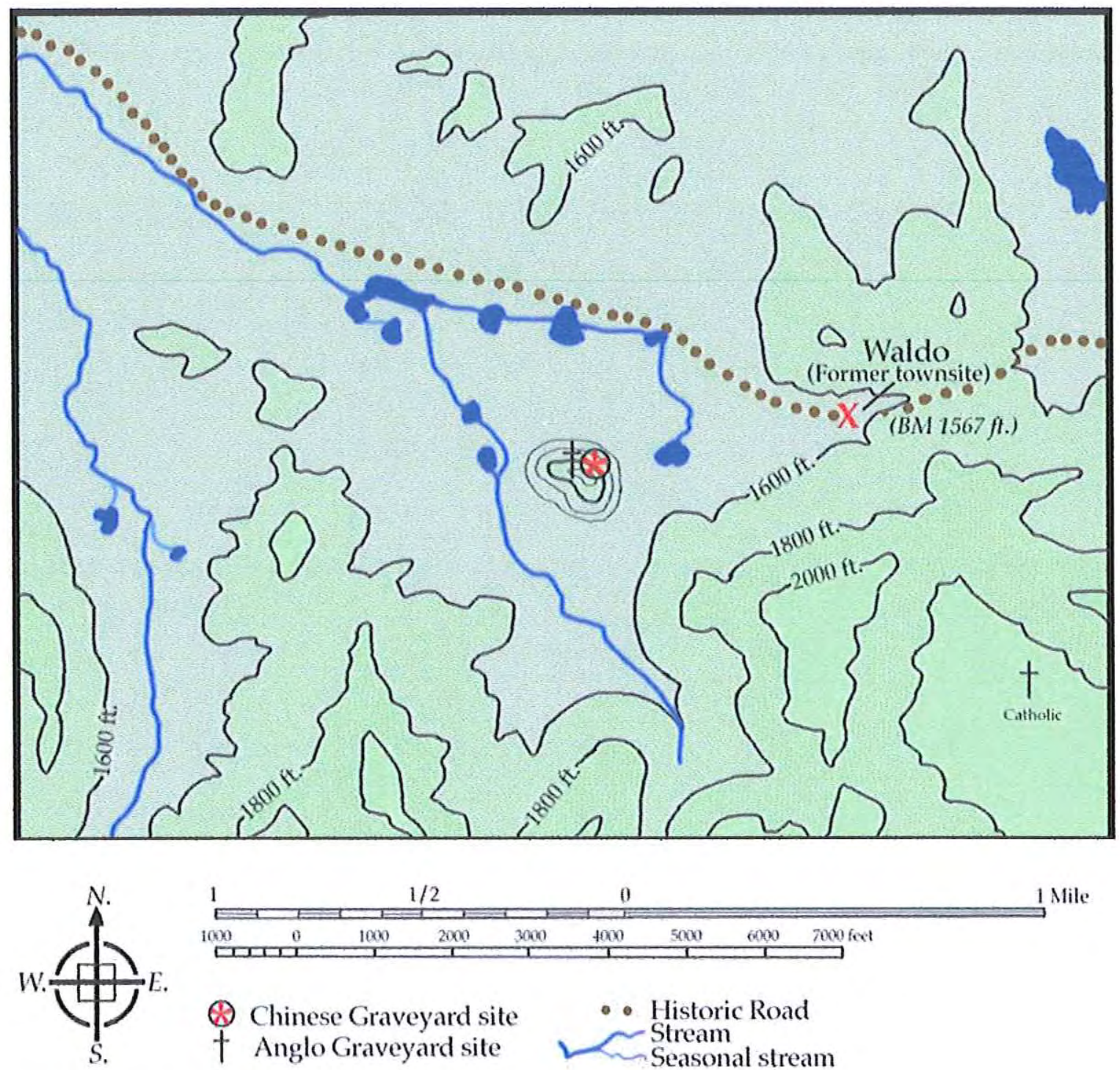
1 Mile

Figure 15: Waldo

"About one half-mile from the site of Waldo, west and a little south, located at the top of a small wooded hill is the Waldo Cemetery. The separation of races is clearly shown there. Many pioneers rest in the cemetery at the top of this hill but the Chinese could not bury their dead there so, some distance down the hillside, they laid their beloved ones to rest" (Pfefferle, 1977:36).

Waldo no longer exists, but the former town was located five miles east of O'Brien, Oregon. Go one mile south of the intersection of CR5560 and Suncrest Avenue, near Fry Gulch - the road requires 4-wheel drive. At the bottom of the hill to the north side of the existing Waldo cemetery you'll find the site covered with shrubs and tall grass. 


\section{Lost or uncertainly located Graveyards}

Auburn (Not located):

Auburn was the largest town in Oregon in 1865 , yet as soon as the gold panned out the town was abandoned, and it is now scrub field seven miles south of Baker City. Auburn had two Chinese cemeteries on the hillside above the town, but the hill was hydraulically mined for gold in the late $1800 \mathrm{~s}$, and the entire hillside, including the cemeteries and townscape, washed away. The terrain is totally altered. It is now forest and field on the hill to the northeast of the intersection of highway 245 and county road 7 .

\section{Bridgeport/Clarksville (Not located):}

The Chinese had their own little settlement about a mile west of Clarksville... Their cemetery was on the northwest hillside above their town. Their remains were eventually all sent back to China, the last probably around 1915 (Burnt River School History Project: 1981).

Clarksville had a considerably large Chinatown in the 1880 s. None of it survives.

The area is now a dry gulch filled with sagebrush and low shrubs twenty miles southeast of Durkee Oregon. No evidence of the Chinatown or any cemetery can be located. 


\section{Canyon City (Found?):}

"A Chinaman died at John Day on Sunday last and was buried the following day in the Chinese burial lots in Canyon City. A full delegation of Chinamen attended the Funeral procession." (Grant County News-Canyon City, 1886).

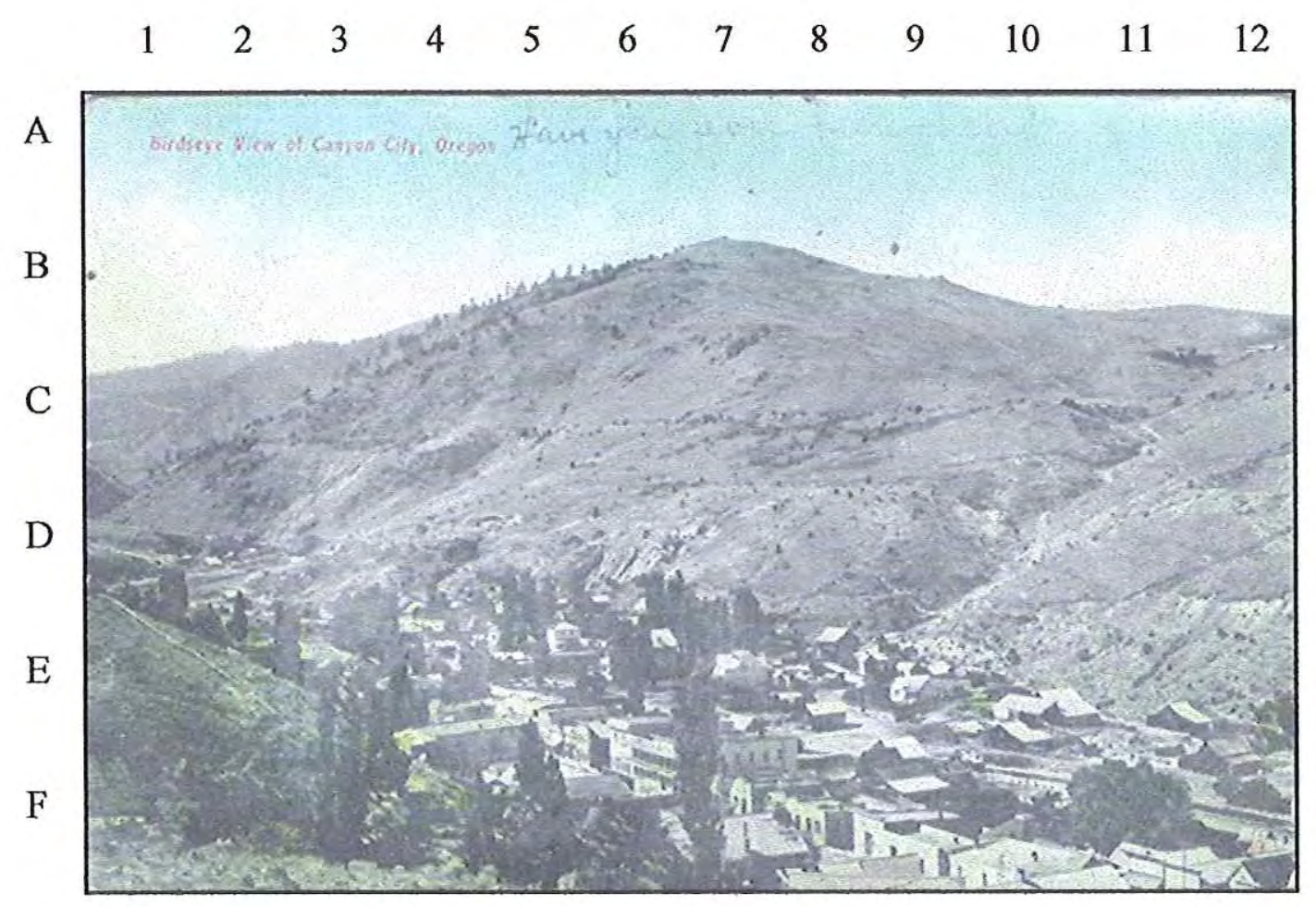

Figure 16: Late 1800s Canyon City postcard looking southwest ${ }^{15}$

Unknown cemetery location. Canyon City's Chinatown was burned down in an arson-related fire in the 1880 s, and the Chinese moved en-masse ten miles north to John Day. The curator of the Herman \& Elisa Oliver Historical museum reported that the Chinese were buried in Canyon City's "boot hill," just below the existing cemetery on the

${ }^{15}$ Figure's 16 and 17 are from an Internet collection held by an unknown private party. Their value lies solely in depicting the landscape, and they are not in themselves of any importance. 
east side of the canyon wall, from where the above photograph was taken. ${ }^{16}$ Another source located the Chinese cemetery on "a hill above town" to the northeast of Canyon City, just to the southeast of the Catholic Cemetery. The two sites are relatively close, but the landscape has been significantly altered.

Conner Creek (unknown):

Nothing is known of this site. Jan Healey, the Oregon Department of Transportation's cemetery specialist reported Chinese burials at this location. ${ }^{17}$ While there were Chinese miners in Conner Creek, I was unable to visit or confirm through other documents. The cemetery is three miles from the Snake River at the old Conner Creek mining camp on Conner Creek, 25 miles north of Huntington.

\section{Coos Bay/Marshfield (Unknown):}

The Coos Bay region had a sizeable Chinese population employed in the salmon canning business in the late $1800 \mathrm{~s}$. One report places a Chinese cemetery on Telegraph Hill, in the northern end of Coos Bay. It has not been confirmed or visited.

16 Personal communication, 1996.

17 Personal communication, 1996. 


\section{Huntington (Found ?):}

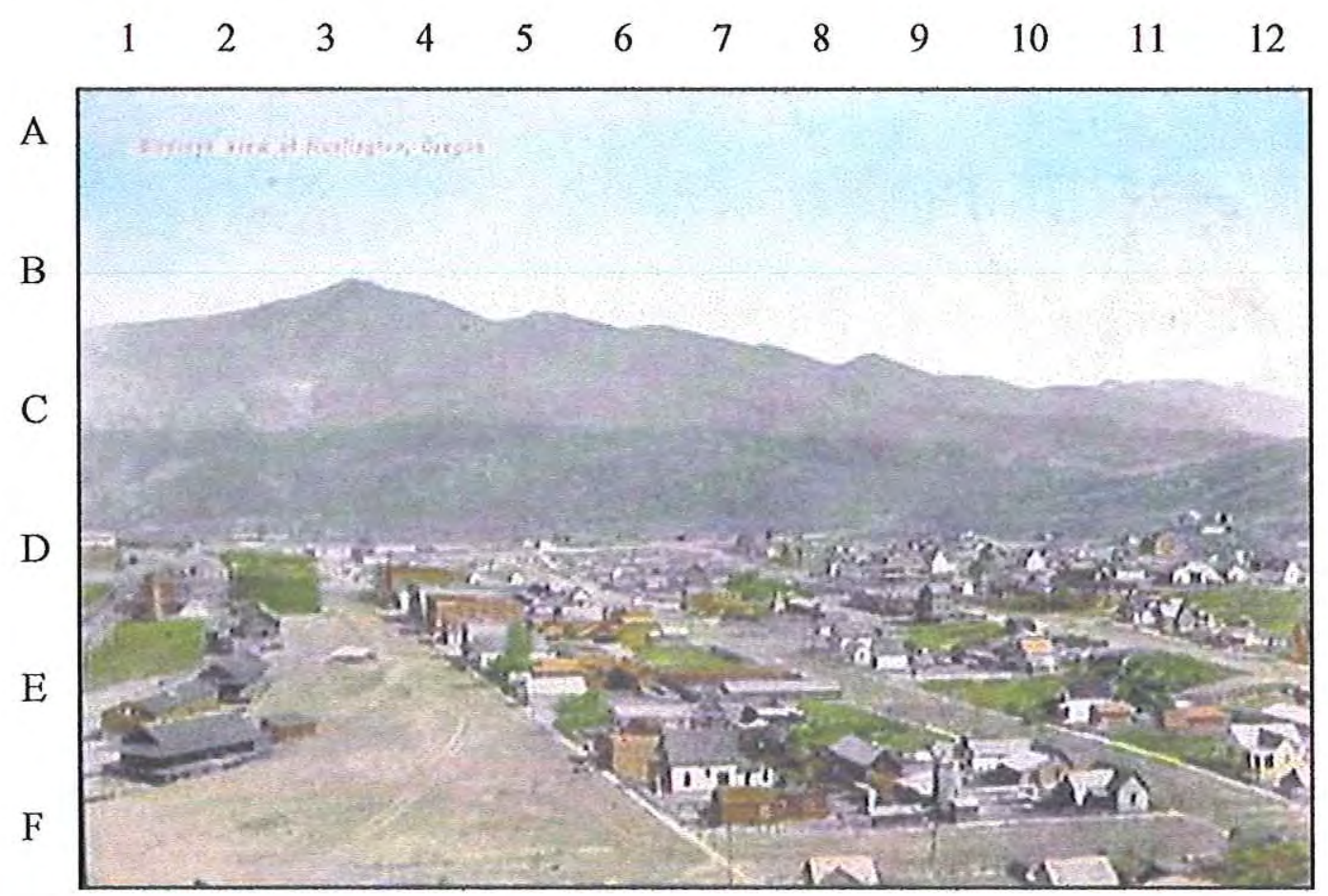

Figure 17: Huntington Oregon postcard, looking southeast, circa 1900. See footnote 15.

"The old Huntington cemetery is located just south of town... at the junction of the old pioneer freight road and the road to Malheur reservoir... It is believed that several Chinese were buried here, however, local opinion has it that most of the remains were exhumed and shipped to China about 1910 (Cummings, 1984).

The mayor of Huntington reported in personal communication that over 1000 Chinese lived in Huntington in the 1800 s. This is doubtful. While Huntington had for a brief time a large Chinese community associated with the railroad, it had no "Chinatown", and no Chinese listed in the 1880 Huntington census. The cemetery is located three blocks south of Highway 30 directly below the city water reservoir. This is up the hill at C, 12 in figure 17 above. The cemetery is unmarked, with no indentations or evidence of any burial sites. 


\section{Portland (Found):}

The portion of the cemetery set apart for the burial of Chinamen is the southwestern part and in that corner a great many celestials "sleep the sleep which knows no waking" (Sunday Oregonian, May 1 1887).

Portland's Lone Fir cemetery was created too late in time to have been used for the first Chinese deaths in the 1860 s, but was in use by the 1880 s. All the Chinese are reputed to have been removed in the 1920 s and the land in the southwest corner of Lone Fir cemetery was paved and built upon. It now is the plant maintenance facility for the cemetery.

\section{Sparta: (found?):}

The Baker City Historical Society curator reported that the Chinese cemetery is located at the logging truck turn-around, $6, \mathrm{D}$ in figure 18 below - marked here with an $\mathrm{x} .{ }^{18}$ Another record placed the Chinese Cemetery "in the gulch east of Sparta" next to the now-deserted Sparta schoolhouse, located at 6, C in figures $18 \& 19$ below (Makinson, 1980:12). The schoolhouse foundation is just above the turn-around, but this gulch is to the west of the former Sparta town site, so the location remains uncertain. The Anglo cemetery remains at 4, B in figures $18 \& 19$.

18 Personal communication, 1995. Trucks going south from Old Ranger Station Road onto the Sparta Road bow out onto a flat area at the junction of the two roads. 


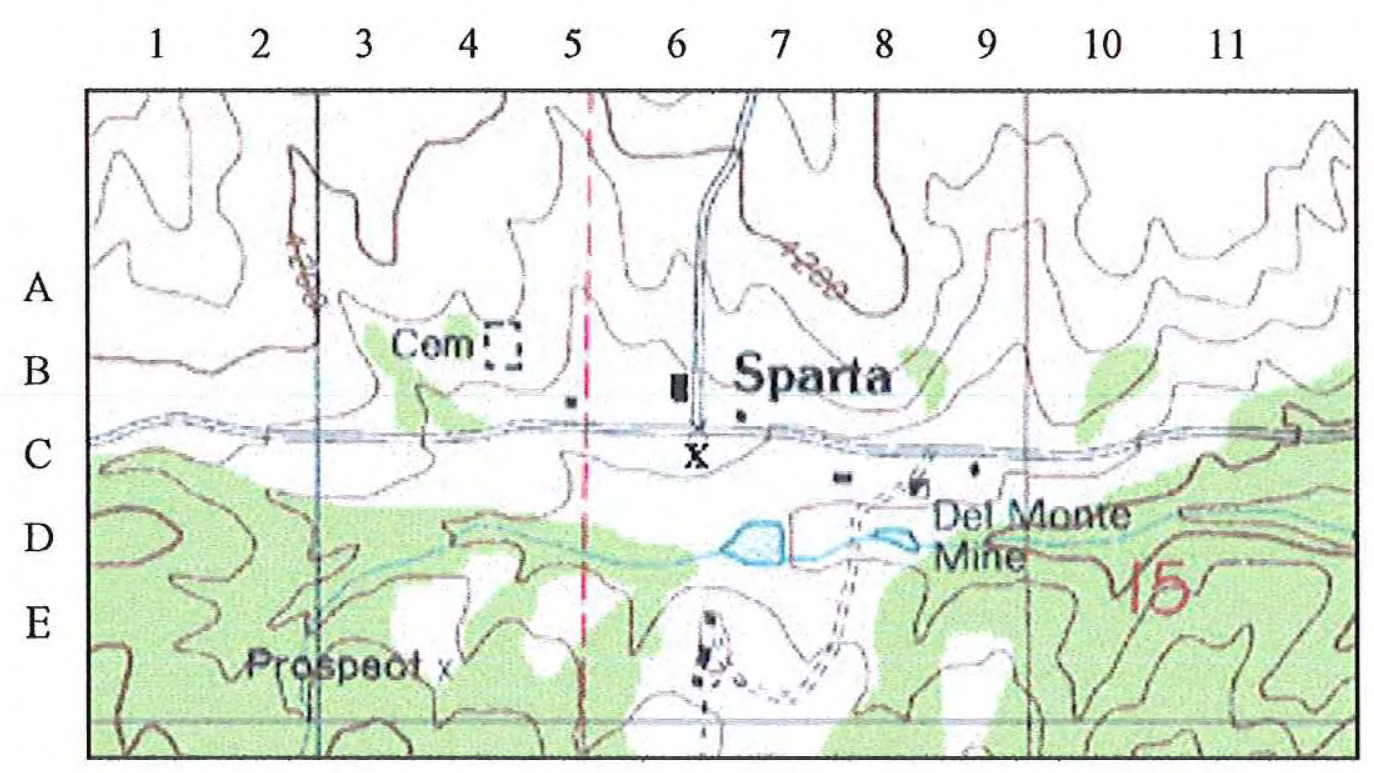

Figure 18: Detail from Sparta Oregon 7.5 topographic map

Sparta had over 175 Chinese living in its Chinatown in the 1880 census, but the cityscape of Sparta is now gone, and no documents or contemporary photographs could be found to help locate the Chinatown or Chinese cemetery. The recent photograph below in Figure 19 was taken from 1, $\mathrm{C}$ in Figure 18 facing east.

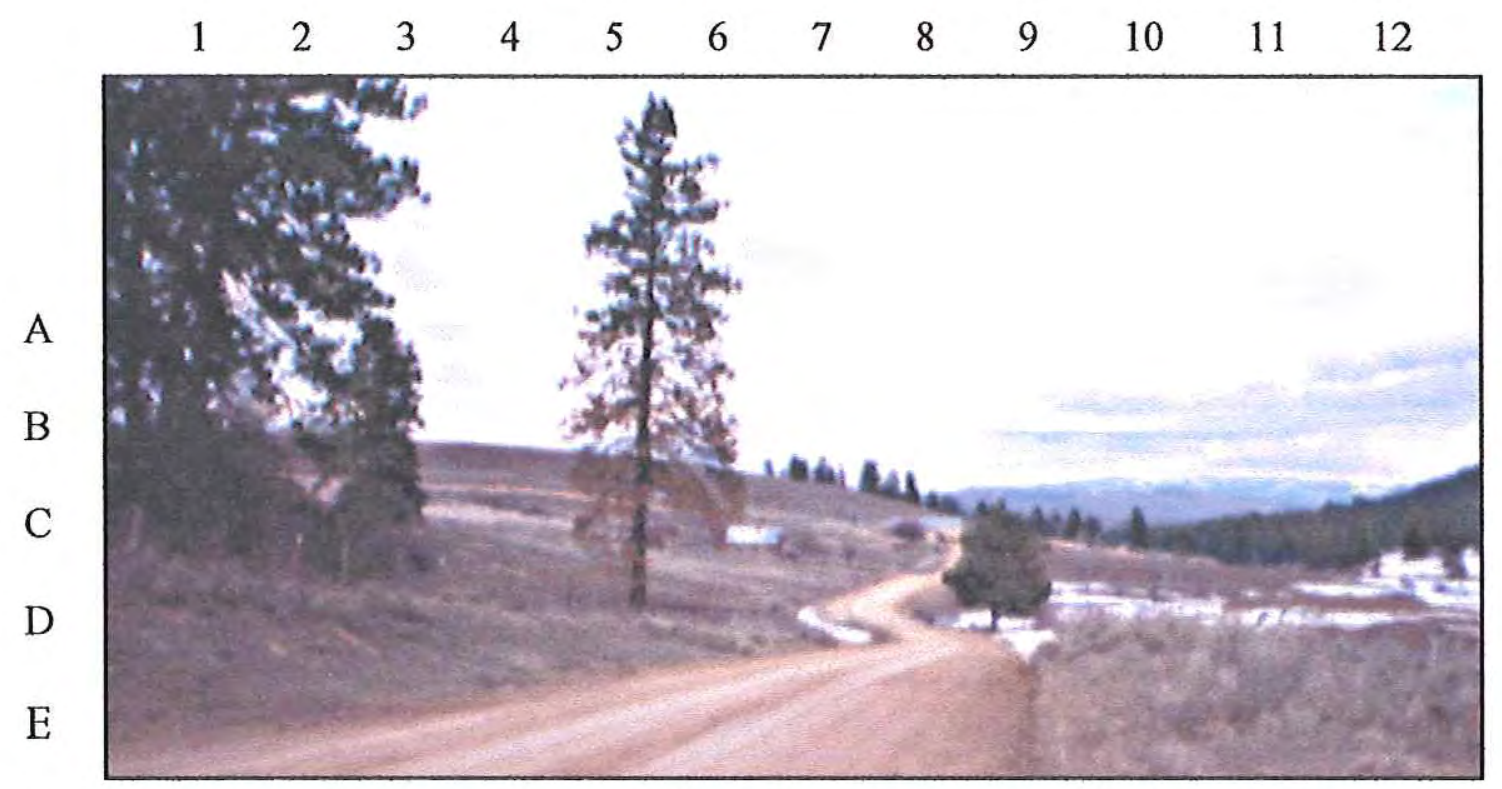

Figure 19: Sparta Oregon (Photograph by author) 
Sumpter: (Found?)

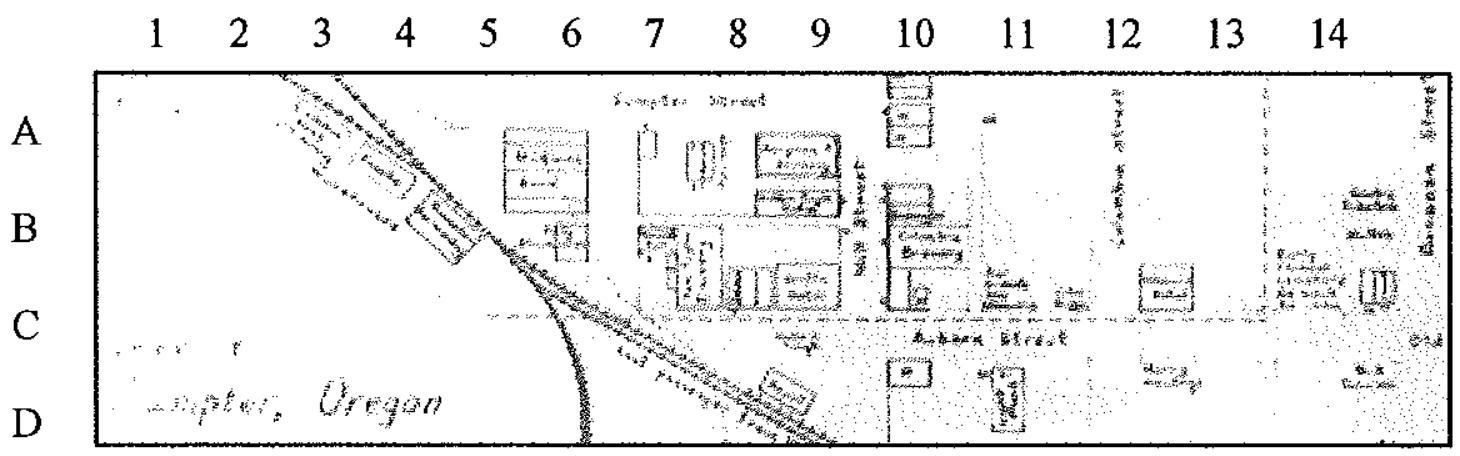

Figure 20: Detail from Brooks Hawley's Sumpter map

Sumpter native Brooks Hawley drew the map in figure 20 depicting the turn-of-thecentury Sumpter Oregon, (Hawley map, Baker Historical Society, Baker, Oregon collection T-72). Hawley has at the corner of Bonanza and Auburn street (14, C above) written "[e]arly Chinese Cemetery -- all [shipped] back to China." This would be an unusual Chinese graveyard site, as the intersection of Bonanza and Auburn was close to the Anglo residential community and on the opposite side of town from Chinatown, which was along Cracker Creek, near 1, A above. The Sumpter Episcopal Church now stands at this site with no evidence of past burials on the lot.

The Daughters of the Revolution 1955 Cemetery Index located the Chinese cemetery within the Sumpter city cemetery, but were not specific in location, and the cemetery is very large. The Sumpter Cemetery is located just off the State Highway 7 about one mile south and east of Sumpter.

The Dalles (developed):

Paula Kutner, the attendant of the Fort Dalles Museum stated that the Chinese cemetery was located just to the west of "Pioneer Cemetery" at the head of Jefferson 
Street. Kutner believed that all of the Chinese bodies had been exhumed at the turn of the century. (Kutner personal communication, 1996). A housing development and roadway were recently erected on the site.

\section{General Remarks on Feng Shui and Oregon Chinese Cemeteries}

The above descriptions is a comprehensive list of known Chinese cemeteries in

Oregon. Of the ten best-ascertained sites, eight are on surfaces sloping downward, facing north, the exceptions being Granite (facing southwest); and Jacksonville, (facing northeast). Every site is raised slightly above either the valley floor, and if in a hilly region, above the lowlands, yet not too high up a hill. The maps above show, with one exception, that every cemetery is located in the second lowest contour field. The exception, Baker City, appears to lie in the lowest contour field -- yet this is misleading. I visited Baker City, and found the site to be nestled approximately 40 to 60 feet above the very flat Baker Valley, with a good view northward.

Many variables influence graveyard/cemetery selection, and feng shui cannot be viewed as the sole determinant of location. That said, most of the gravesites are located on a north-facing slope, slightly above the water table, on a gentle slope with slight erosion. Almost all of these sites would satisfy traditional Kiangsi feng shui requirements. 


\section{Conclusion}

This paper started as a relatively simple exercise: first to locate Chinese cemeteries, and then to test these sites for geographic commonalities which could have originated from traditional Chinese feng shui usage.

This turned out to be hard to do.

First, feng shui is not codified, and reflects a plastic, flowing relationship between the Chinese practitioners and the environment. While feng shui may reflect "Evolutionary Stable Strategies" along the Yellow River in China, it is much trickier to ascertain in the dry American West. It is orphaned from the environmental patch it occupied, and thus may never have been an issue for the early Chinese in America.

Second, intent is hard enough to glean with living, breathing subjects. Trying to ascertain where and why cemeteries were located 100 years ago simply from the geographic location may be impossible.

Third, there are many variables. Here, early land-use laws, individual choice, traditional Chinese custom and Anglo pressures all played a part in where cemeteries were located, and for what purpose. To articulate feng shui from these other variables may not be possible. Yet the Oregon cemeteries of the early Chinese immigrants do share geographic commonalities, and these may be due, at least in part, to the geographic principles of fend shui. 


\section{Bibliography}

Ahern, Emily M. The Cult of the Dead in a Chinese Village. Stanford, CA: Stanford University Press, 1973.

Alexander, Maud Grant. Uncle Dave Discovers Gold. Pendleton, OR: East Oregonian Publishing, 1972.

Andrews, Wesley. "Baker City in the '80s: Boyhood Memories." Oregon Historical Society 50 (June, 1949) pp. 83-87.

Anonymous. "Eastside Cemeteries: Lone Fir and St. Mary's." Oregonian, 1 May 1887, reprint ed., "Pioneer Cemeteries." Portland, OR: Metro.

Baker, Hugh. A Chinese Lineage village :Sheung Shui. Stanford, CA USA: Stanford University Press, 1968.

Barlow, Jeffrey and Richardson, Christine. China Doctor of John Day, Portland, OR: Binsford \& Mort, 1979.

"Historic Chinese Sites in Oregon". In The Chinese in Oregon: A Resource Directory. Portland, OR: Portland State University, 1989.

Burnt River School History Project, 1980-1981. In This Place: A collection of history of Ironside, Unity, Hereford and Bridgeport area of Eastern Oregon. Baker, OR: ESD, 1981.

Cartier, Carolyn L. "Creating Historic Open Space in Melaka." The Geographical Review 83(4), 1993.

Chen, Chia-Lin. "A Gold Dream in the blue Mountains: A study of the Chinese Immigrants in the John Day Area, Oregon, 1870-1910." Master's Dissertation, Portland State University, 1972.

Chinn, Thomas W., et al., eds. A History of The Chinese in California: A Syllabus. San Francisco: Chinese Historical Society of America, 1984.

Clark, Hugh. Portland's Chinese: The Early Years. Portland, OR: Ethni-City Series, 1975, revised 1978.

Coach, Sam. "Topophilia and Chinese miners: place attachment in north central Idaho" Ph.D. thesis, University of Moscow, Idaho, 1996.

Coolidge, Mary. Chinese Immigration. New York: Henry Holt, 1909.

Cummings, Suzie; Barker, Marge; and McLean, Erma. A Pictorial History of Huntington, Oregon and Surrounding Areas. Huntington, OR: Huntington Chamber of Commerce, 1984.

Edson, Christopher Howard. The Chinese in Eastern Oregon, 1860-1890. San Francisco: $\mathrm{R}$ and $\mathrm{E}$ research Associates, 1974.

Freednian, Maurice. The Study of Chinese Society. Stanford, CA: Stanford University Press, 1979.

Fretwell-Johnson, Hazel R. In Times Past: A History of the Lower Jordan Creek Communities. Ontario, OR: Print Shoppe, after 1988.

Grant County News, I880-1890, compiled Janise J. Justice, (Mimeograph). 
Kwok, Man-Ho and O'Brien, Joanne. The Elements of Feng Shui. Rockport, MA: Element Press, 1991.

Lund, D. A. [Charles O. Olson] "Lone Fir - Silent City of the Dead: Resting Place of Portland Pioneers." before 1947, reprint ed., "Pioneer Cemeteries." Portland, OR: Metro, mimeograph.

Makinson, Clyde L. "History of Sparta, Oregon." Baker, OR: Baker County Public Library, 1980 (Mimeographed.)

Micnheimer, Mrs. Curator of the Kam Wah Chung Museum, John Day, Oregon. Interview, August, 1995.

Nave, Edna. "Eagle Valley". (Mimeograph)

Nee, Victor G. and Nee, Brett de Bary. Longtime Californ': A documentary Study of an American China town. New York: Pantheon Books, 1973.

Oliver, Herman. Gold and Cattle Count'y. Portland, OR: Binsford \& Mort, 1961.

Penner, Liisa. The Chinese in Astoria, Oregon, 1870 - 1880: A look at local newspaper articles, the census and other related materials." Astoria, OR: Penner, 1990.

Pfefferle, Ruth. Golden Days and Pioneer Ways. Grants Pass, Or. : Josephine County Historical Society, 1977.

Rand, Helen B. Gold, Jade and Elegance. Baker, OR: Baker Courier, 1974.

Sisley, E. M. "Greeks, Mexicans and Chinese; Chinese Funeral; Pigtails" Huntington, OR: Weiser Signal American Newspaper, 1949. Reprint ed., Huntington's Past: 1860-1954, Huntington, OR: Huntington High School, 1975.

Tabor, James W. Granite \& Gold; The story of Oregon's Smallest City. Baker City, OR: Record Courier Printers, 1988.

Takaki, Ronald. A Different Mirror: A History of Multicultural America. Boston: Little, Brown and Co., 1993.

Umatilla Historical Society. Pioneer Trails Pendleton, OR: Umatilla Historical Society, 1992.

Umatilla Historical Society. Umatilla County: A Backward Glance. Pendleton, OR: Umatilla Historical Society, 1981.

Wegars, Priscilla, ed., Hidden Heritage: Historical Archeology of the Overseas Chinese. Amityville, NY: Baywood Publishing, 1993.

. The Ah Hee Diggings: Final Report of Archaeological Investigations at OR-GR-16, The Granite, Oregon "Chinese Walls" Site, 1992 through 1994. Moscow, ID: University of Idaho Anthropological reports, No. 97. . Correspondence to Alvin Ward, 21 June 1995. "Baker City's Chinese Cemetery." Moscow, ID: University of Oregon, at press 1997.

Wisdom, Loy Winter. "Memories - 90 years in Baker City" (Mimeograph).

Zhang, Frank. "Feng Shui and GIS." Presented at New Challenges in GIS: An International Perspective -- The 1994 CPGIS Annual Conference, Calgary, Canada, June 13-15, 1994. 